\title{
Environmental Electrokinetics for a sustainable subsurface
}

Lima, A.T.; Hofmann, A.; Reynolds, D.R.; Ptacek, C.J.; Van Cappellen, P.; Ottosen, Lisbeth M.; Pamukcu, S.; Alshawabekh, A.; O'Carroll, D.M.; Riis, C.

Total number of authors:

17

Published in:

Chemosphere

Link to article, DOI:

10.1016/j.chemosphere.2017.03.143

Publication date:

2017

Document Version

Peer reviewed version

Link back to DTU Orbit

Citation (APA):

Lima, A. T., Hofmann, A., Reynolds, D. R., Ptacek, C. J., Van Cappellen, P., Ottosen, L. M., Pamukcu, S., Alshawabekh, A., O'Carroll, D. M., Riis, C., Cox, E., Gent, D. B., Landis, R., Wang, J., Chowdhury, A. I. A., Secord, E. L., \& Sanchez-Hachair, A. (2017). Environmental Electrokinetics for a sustainable subsurface. Chemosphere, 181, 122-133. https://doi.org/10.1016/j.chemosphere.2017.03.143

\section{General rights}

Copyright and moral rights for the publications made accessible in the public portal are retained by the authors and/or other copyright owners and it is a condition of accessing publications that users recognise and abide by the legal requirements associated with these rights.

- Users may download and print one copy of any publication from the public portal for the purpose of private study or research.

- You may not further distribute the material or use it for any profit-making activity or commercial gain

- You may freely distribute the URL identifying the publication in the public portal 


\section{Environmental Electrokinetics for a Sustainable Subsurface}

2 A.T. Lima ${ }^{1,2}$, A. Hofmann ${ }^{3}$, D. Reynolds ${ }^{4}$, C.J. Ptacek ${ }^{5}$, P. Van Cappellen ${ }^{1}$, L.M. Ottosen 6 , S. Pamukcu 7 , A.

3 Alshawabekh ${ }^{8}$, D.M. O'Carroll9, 10, C. Riis'11, E. Cox ${ }^{4}$, D. B. Gent ${ }^{12}$, R. Landis ${ }^{13}$, J. Wang ${ }^{4}$, A.I.A.

4 Chowdhury $^{9}$, E.L. Secord ${ }^{1}$, A. Sanchez-Hachair ${ }^{3}$

5

$6{ }^{1}$ Ecohydrology Research Group, Department of Earth and Environmental Sciences and Water

7 Institute, University of Waterloo, Waterloo, Canada

$8{ }^{2}$ Department of Environmental Engineering, Universidade Federal do Espírito Santo, Vitória, ES,

9 Brazil

103 University of Lille, CNRS, UMR 8187, LOG, Laboratoire d'Océanologie et de Géosciences, 59655

11 Villeneuve d'Ascq, France

$12{ }^{4}$ Geosyntec Consultants, Waterloo, Ontario, Canada

$13{ }^{5}$ Department of Earth and Environmental Sciences and Water Institute, University of Waterloo,

14 Waterloo, Canada

15 6Department of Civil Engineering, Technical University of Denmark, Lyngby, Denmark

167 Department of Civil and Environmental Engineering, Lehigh University, Bethlehem, PA, USA

$17{ }^{8}$ Department of Civil and Environmental Engineering, Northeastern University, Boston, MA, USA

$18{ }^{9}$ Department of Civil and Environmental Engineering, University of Western Ontario, London, ON,

19 Canada

$20{ }^{10}$ School of Civil and Environmental Engineering, Connected Water Initiative, University of New

21 South Wales, Manly Vale, NSW, 2093, Australia

2211 NIRAS, Sortemosevej 19, 3450 Alleroed, Denmark

2312 Environmental Laboratory, USACE Engineer Research and Development Center, Vicksburg, MS,

24 USA

2513 RichLand Consulting, LLC, Wilmington, Delaware

27 Abstract

28 Soil and groundwater are key components in the sustainable management of the subsurface

29 environment. Source contamination is one of its main threats and is commonly addressed using 30 established remediation techniques such as in-situ chemical oxidation (ISCO), in-situ chemical 31 reduction (ISCR; most notably using zero-valent iron [ZVI]), enhanced in-situ bioremediation (EISB), 32 phytoremediation, soil-washing, pump-and-treat, soil vapour extraction (SVE), thermal treatment, 33 and excavation and disposal. Decades of field applications have shown that these techniques can 
successfully treat or control contaminants in higher permeability subsurface materials such as sands, but achieve only limited success at sites where low permeability soils, such as silts and clays, prevail. Electrokinetics (EK), a soil remediation technique mostly recognized in in-situ treatment of low permeability soils, has, for the last decade, been combined with more conventional techniques and can significantly enhance the performance of several of these remediation technologies, including ISCO, ISCR, EISB and phytoremediation. Herein, we discuss the use of emerging EK techniques in tandem with conventional remediation techniques, to achieve improved remediation performance. Furthermore, we highlight new EK applications that may come to play a role in the sustainable treatment of the contaminated subsurface.

Keywords: electrokinetics, remediation, subsurface contamination, plume migration, phytoremediation, bioremediation, ISCO, nano zero valent iron (nZVI), landfill

\section{Introduction}

Soils, sediments and aquifers are fundamental bases for global environmental sustainability and provide essential resources to humans and nature alike (Godfray et al., 2010; Koch et al., 2013; McBratney et al., 2014). Anthropogenic impacts through land-use changes have affected, to differing degrees, the capacity of these geological features to maintain their basic functionality. Nutrient cycling, water retention, provision of physical/chemical stability, storage/filtering/transformation of compounds and sustaining biodiversity are some of the key functions that are an integral part of groundwater and food security (Godfray et al., 2010; Seto et al., 2011; United Nations, 2009). Most fresh water reserves (98-99\%) occur in the subsurface; this means that 8-10 million $\mathrm{km}^{3}$ of freshwater is contained or in direct contact with rock and soil (Margat, 2008; Shah et al., 2007). In an increasingly populated and urbanized world, pollution is widely recognized as a significant challenge to soil and groundwater resources management (FAO, 2003). Efforts to quantify groundwater pollution (Giuliano et al., 1998; Zaporozec, 2002) are scarce and the actual scale of the problem is not well known. Point-source pollution (i.e., the source of many groundwater plumes) is often difficult to accurately locate and address, as depicted in Figure 1. The causes of point-source contamination may be varied: industrial leakage (Gent et al., 2004; Lima et al., 2012a), backfill in construction works (Laethem and Legrand, 1993), or overall urbanized environments (Callender and Rice, 2000; Yongming et al., 2006). Source pollution treatment (A in Figure 1) is key to limiting contaminant transport to the vadose zone environment (Dresel et al., 2011) and subsequent migration to the

a sink for contaminants however with time can switch to being a source of long-term contamination. 
Contamination in low permeability materials remains a significant and unresolved remediation challenge. A large contaminant source has the potential to generate a significant plume in groundwater, and presents a risk to potential downgradient receptors (A in Figure 1). A unique form of contaminant transport occurs with dense non-aqueous phase liquids (DNAPLs), including chlorinated solvents, polychlorinated biphenyls (PCBs), coal tars etc. since they tend to sink to the bottom of aquifers due to their density (Macdonald et al., 2000). Contaminants in the context of groundwater exposure pathways are varied, and can consist of organic molecular compounds, nanosubstances, pharmaceuticals, immiscible liquids, and are often toxic at very low (part per billion) concentrations. New ingenious approaches are needed for in-situ (and ex-situ) remediation of soils, sediments and aquifers, particularly when they are comprised of low permeability materials.

Recent successes in electrokinetic (EK) or EK assisted remediation programs have demonstrated that the technique may be a viable and versatile remediation tool for low permeability soils and sediments. EK approaches generally consist of the application of a direct current (DC) electric field to the subsurface through electrodes to move porewater or migrate contaminants or remediation amendments. EK approaches have wide applicability, from soil dewatering (Lockhart and Stickland, 1984; Yang et al., 2005) to desalination of built environments (Ottosen and Rorig-Dalgaard, 2009), removal of soil metal contaminants (Jensen et al., 2007; Ottosen et al., 1997; Pamukcu et al., 1997; Pamukcu and Wittle, 1992) or degrading/removing soil organic contaminants (Lima et al., 2012a; Lima et al., 2011; Pamukcu, 1994; Reddy et al., 2011; Saichek and Reddy, 2004, 2003), including immiscible oil constituents (Ghazanfari and Pamukcu, 2014; Pamukcu et al., 2016). First used at the beginning of the last century for dewatering and stabilizing clays (Casagrande, 1949; Reuss, 1809), EK was intensively studied in the 1990s for removing metals from soils (Acar and Alshawabkeh, 1993; Lageman, 1993; Ottosen et al., 1997; Ottosen and Hansen, 1992; Schultz, 1997), as well as radionuclides and other inorganic species(Acar et al., 1995). More recently EK has been used in various formulations for the removal of organic contaminants (Lima et al., 2011; Pamukcu, 1994; Ribeiro et al., 2005). The approach has been highly successful at the laboratory scale for both inorganic and organic contaminants and in recent field trials for organic contaminants. Field-scale in-situ applications are becoming more common, and have demonstrated the potential of the approach. In spite of promising early results at a variety of scales, the technology has not yet advanced to a commonly-accepted commercial status. 
EK applications in recent years have integrated chemical surfactants, chemical amendments and chelating agents to enhance metals or organics desorption from soil (Bolan et al., 2014; Lima et al., 2012b; Ottosen et al., 2012), or to degrade contaminants at their source. Migration of these chemical enhancers in low permeability soils is possible due to four key phenomena occurring when a direct current is applied to soil: electromigration (movement of charged ions), electro-osmosis (movement of pore water), electrophoresis (movement of colloids) and electrolysis (water splitting) (Acar and Alshawabkeh, 1993). Coupling these phenomena with the aforementioned conventional remediation techniques has been the focus of recent EK research (Cameselle et al., 2013a; Lageman and Godschalk, 2007; Pamukcu et al., 2004). In addition to coupling with existing approaches, EK has been demonstrated to be capable of stripping micropollutants, especially non-polar compounds including heavy oils, from low permeability soils and sediments, where other treatment methods may fail (Alcántara et al., 2012; Ghazanfari et al., 2012; Lima et al., 2012b; Pamukcu, 2009; Pazos et al., 2010). Other EK applications are currently being researched for instance the off-site removal of soil metals (Jensen et al., 2007; Ottosen et al., 2012) and a stand-alone technique for oil transport and recovery from geological media including soils, sediments and rock formations (Chilingar et al., 1968; Ghazanfari et al., 2014; Ghazanfari and Pamukcu, 2014; Ghosh et al., 2012; Pamukcu, 1994; Pamukcu et al., 2016; Wittle et al., 2011).

EK approaches face some unique engineering challenges mainly due to the side effects associated with this technique, such as alteration of natural $\mathrm{pH}$ levels near the electrodes, potential enhanced weathering of the porous media during long-term applications, hydrogen and chlorine gas generation at the electrodes and/or other unpredicted redox reactions (Acar and Alshawabkeh, 1993; Ottosen et al., 2000). Some of these side-effects (Acar and Alshawabkeh, 1993) have been engineered to advantage as synergistic effects beneficial for other traditional soil techniques, such as ISCO (USEPA, 2006), EISB (Mao et al., 2012; Niqui-Arroyo and Ortega-Calvo, 2007) and phytoremediation (Aboughalma et al., 2008; Cameselle et al., 2013a; Kubiak et al., 2012). Field scale application of EKcombined remedies has recently been demonstrated at sites in Denmark and the USA (Mao et al., 2012; Riis et al., 2012).

EK has been the topic of a number of review papers, each of which focused on one facet or another of this technique. Yeung (Yeung, 2011) takes a historical approach, Cameselle et al. (Cameselle et al., 2013b) focused on the combination of phytoremediation and EK, Pamukcu (Pamukcu, 2009) on electrochemical treatise, others on specific contamination (Gomes et al., 2015; Saichek and Reddy, 
2005). EK is an approach with the capacity of overcoming traditional problems in soil remediation practices. The technique can be applied in-situ in a manner that avoids soil excavation and minimizes the disturbance of soil texture, porosity and biodiversity (Saichek and Reddy, 2005; Virkutyte and Sillanpaa, 2002). Treatment costs are variable depending on the contaminant, approach, and other site-specific factors, but are in line with other intrusive in-situ approaches (Virkutyte and Sillanpaa, 2002). Due to low soil disturbance, low water and energy usage, EK is often less expensive than other remedial techniques (Alshawabkeh and Acar, 1992; Gomes et al., 2015; Higgins et al., 2008; Wittle et al., 2011; Yang et al., 2011). Herein, we discuss the strength of EK as a complement to traditional soil and groundwater remediation techniques and explore future avenues for EK as a sustainable subsurface remediation approach.

\section{Conventional soil remediation techniques for source control and their limitations}

Commonly practiced technologies for soil and groundwater remediation include permeable reactive barriers (PRBs) (Benner et al., 2002), bioremediation (Guerin, 1999; Tromp et al., 2012), i.e. the use of either plants (phytoremediation) or microorganisms (bioremediation) to degrade, accumulate or reduce/oxidize chemical contaminants, soil-washing (Meuser, 2012), pump-and-treat (Meuser, 2012), in-situ chemical oxidation (ISCO) and in-situ chemical reduction (ISCR), the use of chemicals to oxidize or reduce redox sensitive contaminants in high porosity soils and sediments, vapourtechnologies to volatilize organic contaminants, thermal approaches to vapourize organic contaminants and remove them through vacuum extraction, and "dig-and-dump". The majority of these approaches (with the exception of thermal and dig-and-dump) have significant limitations when contaminants to be treated reside in low permeability regions. Table 1 summarizes the main characteristics and main challenges of bioremediation, phytoremediation, nano-particles, ISCO, thermal, and landfilling (dig-and-dump). As mentioned previously, a number of these techniques can be combined with EK to increase their suitability for treatment of contaminants in low permeability regions. A summary of the techniques that can be enhanced using EK, and a brief synthesis of the target contaminants and major limitations is presented in the next sections.

Bioremediation is a cost-effective technique for treating a variety of contaminants, including chlorinated solvents, BTEX, selected inorganic substances (e.g., perchlorate and nitrate) and polycyclic aromatic hydrocarbons (PAHs) (Liebeg and Cutright, 1999; Sturman et al., 1995; Vidali, 2001). Major bioremediation techniques broadly fall into two categories: biostimulation and bioaugmentation. Biostimulation most commonly refers to the addition of nutrients, such as electron 
acceptors or electron donors, to promote biodegradation of contaminants by indigenous microbes. Bioaugmentation most commonly refers to the addition of microbes possessing specific capabilities to biodegrade contaminants. A number of factors can hinder bioremediation processes, including limited physical interaction between microorganisms and substances (contaminant bioavailability and/or bioaccessibility) (Semple et al., 2004); adverse site conditions (temperature, high cocontamination(Straube et al., 2003), pH, salts, oxygen, etc.) that may be inhibitory or toxic to microorganisms (Wick et al., 2011); and lastly, absence of bacterial species that can degrade the target contaminant.

Phytoremediation is a low-cost and environmentally acceptable solution for the remediation of shallow soils, soil water and runoff for both metals and organic contaminants e.g., (Chaney et al., 1997; McCutcheon and Schnoor, 2004; Tromp et al., 2012). Phytoremediation is highly suitable for metals contamination as plants are capable of concentrating metals and extracting them from soils (Pilon-Smits, 2005). However, remediation occurs at a shallow soil depth (root zone) and may require extended remediation time. Solutions may include deep planting of trees in boreholes (treewells), and the use of polluted groundwater for plant irrigation (Pilon-Smits, 2005).

ISCO for groundwater remediation was first introduced in the 1990s as an aggressive in situ technique to address groundwater contamination without requiring soil excavation (Innocenti et al., 2014; Schnarr et al., 1998; Yukselen-Aksoy and Reddy, 2012). Four oxidants have been commonly used: hydrogen peroxide (Fenton's reagent), ozone, permanganate, and persulfate (USEPA, 2006). Permanganate and persulfate oxidant stability in the subsurface is high, and natural soil oxidant demand for these particular oxidants is potentially low, making ISCO an attractive, cost-effective remediation technique, especially in high hydraulic conductivity material (Ferrarese et al., 2008; O'Mahony et al., 2006; USEPA, 2006). The major limitations of ISCO are related to the hydrogeological conditions: ISCO is more effective in medium to high permeability material, while less effective in low permeability soils (such as clay, loams, glacial tills, hydromorphous soils) as advective transport of oxidants is dramatically decreased (USEPA, 2006). A high content of reduced substances, such as Fe(II), in the soils to be treated may trigger oxidant activation before delivery to the contaminant location (Benner et al., 2002; Petri et al., 2011).

Nano zero valent iron (nZVI) application is a relatively recent remediation technology (Bennett et al., 2010; Elliott and Zhang, 2001; He et al., 2010; Johnson et al., 2013; Kocur et al., 2014) suitable for 
contaminants that can be treated by chemical reduction. Several laboratory-scale experiments have shown that nZVI can remediate a wide range of contaminants such as nitrate anions (Suzuki et al., 2012; Yang and Lee, 2005), heavy metals (Boparai et al., 2011), pesticides (Satapanajaru et al., 2008; Sayles et al., 1997), PCBs (Wang and Zhang, 1997), chlorinated volatile organic compounds (cVOCs) (Sakulchaicharoen et al., 2010; Song and Carraway, 2005) and radionuclides (Roh et al., 2000). Fieldscale studies have used commercially available nZVI (Henn and Waddill, 2006; Krug et al., 2010; Wei et al., 2010) or onsite synthesized nZVI (Bennett et al., 2010; Elliott and Zhang, 2001; He et al., 2010; Kocur et al., 2014; Wei et al., 2010; Zhang, n.d.) that were either unstablized (Elliott and Zhang, 2001; Zhang, n.d.) or polymer coated (0.10\%-0.80\%, weight/volume) to increase suspension stability (Bennett et al., 2010; He et al., 2010; Henn and Waddill, 2006; Kocur et al., 2014; Wei et al., 2010). A major challenge for nZVI is delivery time: it needs to be delivered to the target treatment zone while reactive and in suspension (e.g. days to a few weeks) (Kocur et al., 2014, 2013; Sakulchaicharoen et al., 2010). As with other chemical in-situ remediation techniques, most successful field studies have been performed in highly permeable soils. Fine grained soils limit nZVI travel distances (Chowdhury et al., 2012).

Landfilling, often referred to as a "dig-and-dump" approach, is considered one of the least sustainable remediation approaches (EEA, 2009). Excavation and landfill disposal of contaminated soil resolves site problems immediately and can be used widely regardless of pollution type and soil characteristics. From a sustainability standpoint, landfills should be considered a last resort for waste. They are expensive in terms of land (area that is allocated for this purpose, with few examples of rehabilitation post-exploitation); fees for hazardous waste disposal are high (US EPA, 2014); and the environmental cost is also considerable, since leachate emission poses an additional threat to groundwater quality. Additionally, landfills constitute a subsurface legacy, transferring waste and groundwater contamination issues to future generations (Bai and Sutanto, 2002; EEA, 2009).

The following section examines how EK approaches can be used to enhance bioremediation, phytoremediation, ISCO and nZVI, since these are already tried-out combinations. Particular focus is given to bioremediation enhanced by EK (EK-BIO) which has been demonstrated to be highly effective in field-scale studies, and ex-situ soil remediation for metals.

\section{EK in combination with conventional techniques: How is EK overcoming limitations?}


An electric field is applied to a porous media, including saturated soil or sediment, that (i) drives ions present in the media towards one of the electrodes - electromigration, (ii) moves pore water when soil porosity and zeta potential is conducive - electro-osmosis, (iii) mobilizes colloids when soil macropores are sufficiently large to enable their passage - electrophoresis, and that (iv) instigates electrolysis, i.e. generation of an acidic front from the anode and alkaline front from the cathode (Acar and Alshawabkeh, 1993; Lageman, 1993; Mitchell, 1993; Ottosen et al., 2000; Pamukcu and Wittle, 1992). Due to the many different phenomena that may occur during the use of an EK approach, EK requires sound engineering to control potential side-effects. Early applications of EK technology did not effectively manage potentially negative processes and hindered early field applications (Alcántara et al., 2012; Gent et al., 2004; Lima et al., 2012b; Reddy and Cameselle, 2009; Simons, 1984). More recent research and field experience has overcome early difficulties. EK approaches are significantly favoured over most other in-situ techniques when it comes to low permeability soils(Cameselle and Reddy, 2012; Ghazanfari et al., 2012; Paillat et al., 2000) due to the increased ability to drive remediation amendments to the contaminants, extract contaminants directly, and its limited impacts on soil structure.

\subsection{Sustainability of EK Approaches}

Sustainability principals are being increasingly recognized as important considerations in the remedy selection process (Hadley and Ellis, 2009). SURF (Sustainable Remediation Forum) defines sustainable remediation as those practices that reduce global impacts at the same time as minimizing local atmospheric effects, potential impacts on worker and community safety, and/or the consumption of natural and energy resources that might be attributable to remediation activities (Hadley and Ellis, 2009; ITRC (Interstate Technology Regulatory Council), 2011). As presented in Table 1, even the most promising techniques present limitations.

EK inherently uses electrical energy, which can be from fuel sources (Lima et al., 2012a) or from renewable sources (solar, wind) (Zhang et al., 2015). Despite electric energy being at the base of the technique, the sustainability score for EK approaches is high, as the consumption of renewable resources, such as water, is low, use of electricity is small compared to other techniques, it generates minimal waste, and has limited impact on local surface activities. Recent field applications have used a closed water circuit for EK, where only groundwater is used and no external water input is necessary (Mao et al., 2012; Riis et al., 2012). 


\subsection{EK Enhancement of Traditional Approaches}

Bioremediation presents a number of limitations, including the need to control abiotic conditions, mass transfer challenges, bioavailability, bioaugmentation and potentially high operation or longterm re-application costs (Vidali, 2001) (Table 1). EK has been used to surpass some of these challenges, such as control of physico-chemical conditions of soil (Niqui-Arroyo et al., 2006), decrease mass transfer limitations through nutrient transfer and stimulating bioactivity and controlling bacterial population (Mao et al., 2012; Tyagi et al., 2011). Deflaun \& Condee (DeFlaun and Condee, 1997) first enhanced migration of bacteria through soil, while Mao et al. (Mao et al., 2012) applied the same principle as a bioaugmentation tool for the remediation of chlorinated solvents. Different EK principles have been used: electro-osmosis or electrophoresis to mobilize bacteria (Figure 2) (DeFlaun and Condee, 1997; Wick et al., 2004) and electromigration to drive nutrients in low porous materials (Gill et al., 2014; Mao et al., 2012). After successful lab trials, the patented EKBIO has been applied in-situ (Luo et al., 2006) with considerable success (Riis et al., 2012). Some bioremediation drawbacks (primarily challenges with nutrient distribution in low permeability soils) may thus be addressed remarkably with EK, but evidently target contaminants still need to be biodegradable. EK-BIO has been used primarily on the degradation of organic contaminants, but can also be used for biodegradation of nitrates and perchlorate (Mao et al., 2012; Riis et al., 2012).

Phytoremediation has shown positive results for the in-situ remediation of both metals and organics. While promoting the degradation of organic contaminants (Kamath et al., 2004; Pilon-Smits, 2005), plants can assimilate and bioaccumulate metals (Ali et al., 2013; Chaney et al., 1997; Weis and Weis, 2004). An innovative, however as yet to be field-demonstrated EK combination, is EK-phyto (Figure 2) (Aboughalma et al., 2008; Cameselle et al., 2013a). EK can be used to mobilize and redistribute metals in situ, and therefore enhance their transport to the plant roots (Aboughalma et al., 2008). In addition, EK can help stimulate plant growth by mobilizing (micro)nutrients in/to the root zone. Cameselle et al. (Cameselle et al., 2013a) summarized the state-of-the-art regarding the combination of phytoremediation and EK and concluded that laboratory studies yielded the best results with the application of an alternate current (AC) electric field or low direct current (DC) voltage. Therefore, electromigration is used to transfer ions and metals to the root zone while the development of heat (AC electric field) may create ideal assimilation conditions for the plant. Since a low DC field stimulates electroosmosis (Lima et al., 2011), this might explain the improved plant performance under such conditions (Cameselle et al., 2013a). 
Nano-ZVI shows potential to treat redox sensitive contaminants (i.e. organic contaminants in general, 297 or redox sensitive metals) but also stable metal ions, such as divalent $\mathrm{Cd}^{2+}$ (Boparai et al., 2011). 298 Polymer stabilized nZVI particles have a net negative surface charge (zeta potential of -48 to $-56 \mathrm{mV}$ ) 299 (Chowdhury et al., 2012; Kocur et al., 2013) and can adsorb positively charged species. EK has the potential to enhance nZVI transport by electrophoresis. Studies have reported the enhancement of nZVI delivery through coarse and medium grained soils (Chowdhury et al., 2012) while others found that electroosmosis can enhance nZVI delivery through clayey soil (Figure 2) (Gomes et al., 2013; Krishna R. Reddy, 2007). These studies suggest that EK has the potential for enhanced nZVI delivery throughout a number of different soil types to enable subsequent contaminant degradation resulting from nZVI oxidation. EK-nZVI laboratory studies have shown great potential, but field trials are needed.

Like the other techniques mentioned in this review, ISCO performance in low permeability or highly heterogeneous soils is often a significant unresolved challenge. Commonly used chemical oxidants (permanganate, persulfate) are negatively charged, and highly mobile through electromigration in low permeability soils (Figure 2) (Alshawabkeh, 2009; Nieto Castillo et al., 2012). Electroosmosis or electromigration may also help mobilize specific contaminants (non-charged hydrophobic organics or metals, respectively) by encouraging desorption or transport to different phases (Isosaari et al., 2007; ITRC, 2001). ISCO is a highly commercialized technology, with many different approaches and patented techniques (Table 1; see e.g. (Virkutyte and Sillanpaa, 2002)). EK-TAP (thermal activated persulfate) (Reynolds, 2015) has recently been developed and is currently undergoing field testing at a number of locations in Europe and the USA (ITRC, 2000; Roach and Reddy, 2006; Siegrist et al., 2001). EK-TAP uses a standard DC electric field to migrate persulfate into the contaminated region and then switches to AC to slightly increase the soil and groundwater temperature in the treatment zone $\left(<40^{\circ} \mathrm{C}\right)$ to activate the persulfate.

Remediation of fine grained soils contaminated with metals has historically been performed through landfilling(Reddy, 2010). Landfilling costs are generally higher and less sustainable in the long-term than any in-situ soil remediation (Table 1), in addition to the environmental costs and sustainability considerations addressed elsewhere in this review. When there is no in-situ solution in sight, an alternative to soil landfilling is off-site treatment of soil. This occurs often where brownfields are considered, either for metal (Merkx et al., 2013) or organic pollutants (Gomes et al., 2015; Lima et al., 2012a; Pamukcu, 1994). The electrodialytic remediation (EDR) method has been proposed as a fast 
and continuous in-situ or off-site alternative to landfilling for excavated soil. Promising results through the application of EDR for heavy metal polluted harbour sediment (Nystroem et al., 2005) have been obtained by treating a stirred suspension instead of a stationary matrix. The stirred system for EDR was adapted for the soil remediation, and the soil was suspended in water during the remediation (Gomes et al., 2013; Jensen et al., 2007; Lima et al., 2012b; Ottosen et al., 2012; Sun et al., 2012). Advantages of off-site EDR treatment involve (i) transient and nonlinear changes during remediation that are overcome by the continuous mixing; (ii) the removal rate of heavy metals is faster, as stirring enables mixing and desorption; (iii) easy handling for adding chemical desorbing solutions; and (iv) stirred EDR can be combined with soil washing for minimizing the volume to be treated. In this case the clean coarser fraction and the highly polluted fine fraction are separated during the soil washing and only the fine fraction is treated by EDR. Successful removal rates have been obtained for both metals (Jensen et al., 2007; Ottosen et al., 2012; Sun et al., 2012) and organics (Gomes et al., 2013; Lima et al., 2012b).

Besides aiding traditional technologies, EK has been applied as:

- landfill liner enhancement tool, for contaminant confinement (Ouhadi et al., 2010)

- Extraction of nutrients, like phosphorus, from waste materials (Guedes et al., 2014).

- $\quad$ Radionuclides control in soils/clays (Maes et al., 1999)

- EK as enhancement technology for oxidation of emerging contaminants and pesticides (Linley et al., 2014; López-Vizcaíno et al., 2017);

- And remediating soil by stabilizing/precipitating contaminants in a stable iron-rich band (Cundy and Hopkinson, 2010)

Landfill-liner enhancements have undergone developments since its first patent (Wittle and Bell, 2002). Most recent studies aim at combining chemical stabilisers, such as calcium carbonate, to increase landfill liner contaminant adsorption, with an addition of $28 \%$ weight mass of carbonates (Ouhadi et al., 2010). Clay liners are normally used in landfilling. Combining EK with clay liners has been the focus of numerous studies, from predicting the behaviour of swelling clays under such hydro-electric conditions (Lima et al., 2010; Moyne and Murad, 2002) to removing radioactive elements in clays (Kim et al., 2003; Maes et al., 1999; Valdovinos et al., 2016). The latter approach focused on radioactive liquid organic waste (Valdovinos et al., 2016), ${ }^{24} \mathrm{Na}(15 \mathrm{~h})$ and ${ }^{99 \mathrm{~m} T c}$ (6h) (with $71.8 \%$ and 61\% removal rates respectively) (Valdovinos et al., 2016), and Uranium (23\% removal rate) (Kim et al., 2003). Alternatively, more technical aspects have been used regarding EK. For 
instance, electric fields have been used to generate $\mathrm{pH}$ and Eh gradients to induce in situ precipitation of a stable iron-rich band (Cundy and Hopkinson, 2010), or to engineering stabilise soil by dewatering/rewatering soils, (Cundy and Hopkinson, 2010).

\section{Future avenues for environmental EK}

In the decades since EK was first applied to soil with the intention of removing pollutants (Alshawabkeh and Acar, 1992; Hansen et al., 1997; Lageman, 1993; Pamukcu, 1994), EK has developed into a viable alternative for remediation of source contamination, particularly when combined with other conventional techniques for application to low permeable soils. EK approaches have numerous strengths, such as minimizing land disturbance when applied in-situ, reduced costs in terms of energy and transportation, and as an auxiliary tool to a number of new applications (section 3).

Most site remediation initiatives concern point source pollution. However sources of anthropogenic groundwater pollution are numerous and, many times, diffuse. Plume migration concerns a challenging issue regarding pollution dispersion (B in Figure 1). While the Permeable Reactive Barrier (PRB) concept is currently the leading technology to target downstream pollution effects, previous combination of EK with PRB (EK-PRB) has proven advantageous in terms of treatment, PRB material longevity and cost reduction (Ramírez et al., 2015). The idea was tested at bench and field scale in the 1990ies and coined as the Lasagna Technology (Ho et al., 1995; Sa V. Ho et al., 1999a, 1999b). A wealth of experimental studies have been conducted in EK-PRB (Chung and Lee, 2007; Huang and Cheng, 2012; Moon et al., 2005; Vieira dos Santos et al., 2017; Weng et al., 2007; Zhou et al., 2016) with a rekindled interest in the last 2-3 years. The older studies showed that standard PRBs, including zero valent iron filing for the treatment of chlorinated hydrocarbons and chromate in aquifer settings, can be significantly enhanced by coupling to EK. Recent studies show original combinations of pollutants and PRB treatment materials. In particular, the development of biological reactive barriers is proposed (Mena et al., 2016; Ramírez et al., 2015). In these studies bacterial cultures of active sludge from an urban WWTP and coarse mineral soil (kaolinite, gravels) are used as biobarriers. Biological growth was observed in the biobarrier, and under the effect of the electric field, bacteria from the biofilm became detached and were transported through the diesel contaminated soil in both directions (Ramírez et al., 2015). Added surfactant was transported across the treatment zone due to electromigration and electroosmosis, which resulted in diesel emulsification. After two weeks of operation, the combination of biological and EK phenomena 
resulted in 39\% removal of the diesel biodegradable fraction (Ramírez et al., 2015). In fact, EK has proven great applicability in addressing organic contamination, contrary to the attested regarding its first applications for metal contamination. Further studies are expected in addressing LNAPL and DNAPL plumes and exploring solutions for the interface unsaturated-saturated zones (Dresel et al., 2011). There is a need for sustainable solutions to treat these deep locations and EK-PRB can be the answer to these groundwater issues.

EK techniques are based on the fundamental processes of EM, EO and EP. They had been recognised all by the middle of the XXth century (Casagrande, 1949; Reuss, 1809), but, as pointed out by Yeung (Yeung, 2011), research on the understanding of fundamental phenomena is still needed. Variability in osmotic flow rate, the means of transport of electric current through the soil are still not clearly understood. Here we stress that aspects of soil-contaminant interaction can benefit from further understanding when concerning contaminant removal. It has been shown that, under the influence of an electric field, the phenomena that take place at the interface between matrix and pore fluid are very complex and give rise not only to the dominating processes of EM, EO and EP but to subtle effects related to the complex nature of the solid-liquid and liquid-liquid interfaces present in the porous media. Effects such as diffuse double layer compression, electroosmotic drag or electroosmotically induced displacement give rise to refined or new strategies for soil extraction and remediation. Some new developments emerged that brink between laboratory and pilot scale research:

- In-situ manipulation of redox-state via EK for redox sensitive metals (e.g. Cr, As, Cu) (Brosky and Pamukcu, 2013; Pamukcu et al., 2004; Sun et al., 2015)

In a porous water saturated material, particles typically carry a surface charge that is compensated by the Electric Double Layer (EDL). As electric fields are imposed to this material, a faradaic current is induced which is responsible for electromigration of the unbound aqueous species in the pore water. However, because a conductivity difference exists between the outer part of the EDL and the free pore solution, that outer part - the Diffuse Double Layer (DDL) is compressed while the electric field is applied, leading to a potential difference which adds to the redox potential of the system and can contribute to its reactivity. This EK induced DDL phenomenon has been explored in a laboratory study of $\mathrm{Cr}(\mathrm{VI})$ reduction in clay. It showed that a $0.6 \mathrm{~mA} / \mathrm{cm} 2$ applied current was able to increase the reduction rate of the system by a factor of 5 (Sun et al., 2015). While only $\operatorname{Cr}(\mathrm{VI}) / \mathrm{Cr}$ (III) and $\mathrm{Cu}(\mathrm{II}) / \mathrm{Cu}(\mathrm{I})$ redox couples have been studied experimentally up to date (Brosky and Pamukcu, 
2013; Pamukcu et al., 2004; Sun et al., 2015)), many redox sensitive elements (uranium, selenium, etc) may be candidates for this treatment method.

- Application of EK in the field of oil extraction and oil transport in water wet porous media (Amba et al., 1964; Chilingar et al., 1968; Ghazanfari et al., 2014, 2012; Ghazanfari and Pamukcu, 2014; Haroun et al., 2013; Pamukcu et al., 2016; Shalabi et al., 2012; Wittle et al., 2011) Viscous coupling between oil and water phase takes place when an electrical interface, similar to that of clay electric double layer, develops between the two phases, provided that the oil has polarity and possesses some functional groups (i.e., O, N, S compounds, carboxylic acids, amides). Electrokinetic transport of hydrocarbon liquids in water wet porous media is governed by the principles of two-phase flow. As the water phase moves by electro-osmosis through water wet porous media, the neighboring oil phase is also transported, to an extent, depending on the strength of the viscous coupling developed between the two phases. More so, in water wet systems of clay/saline water/oil, the reactions of the electrolysis products of saline water (i.e., hydroxyl ions) with the carboxylic acids of oil result in the formation of surfactants at the water/oil interface. This, in turn, reduces significantly the interfacial tension between oil and water further aiding the oil transport by electroosmosis (Ghazanfari et al., 2012; Pamukcu et al., 2016). Another interesting phenomenon is observed when the water and oil phases are strictly immiscible and viscous coupling does not take place (Pamukcu et al., 2016). Then the electroosmotic flow of the water can pass by the nonconductive liquid ultimately displacing the oil in opposite direction of flow. This liquid separation process is shown to be particularly efficient when pore space it restricted. Also it favors increase of permeability of the porous media.

Laboratory and field applications research show EK as capable of separate and recover oil from water, aqueous sediments and high clay rock formations, advancing EK to be used as a stand-alone or integrative technique for:

- remediation of oil contaminated soils and sediments where spills have occurred (i.e., coastal sediments, coal gasification sites, abandoned oil production or refinery sites);

- change in physical properties can be triggered via electrokinetic methods as the classic soil consolidation (Adamson et al., 1966) with the aid of calcium carbonate producing bacteria (Keykha et al., 2014);

- product extraction, with special interest for mobilization of crude oil in enhanced oil recovery (EOR) processes (Al Shalabi et al., 2012; Amba et al., 1964; Haroun et al., 2013; Shalabi et al., 
2012; Wittle et al., 2011) from formations where other extraction methods (i.e., drilling) may not be feasible or environmentally viable.

As a final remark, we would like to observe that EK is increasingly used in the remediation of emerging contaminants such as pesticides (López-Vizcaíno et al., 2017; Vieira dos Santos et al., 2017), perfluorinated chemicals and radionuclides (control in soils/clays (Maes et al., 1999)). Novel approaches reside in using new catalytic materials (Linley et al., 2014) or as a means for element recycling in waste materials such as phosphorous (Guedes et al., 2014). Because EK acts as a transport tool for dissolved and colloidal particles, as well as solvent through porous media, the possibilities for futures applications are varied and only limited by inventiveness and possibly limited research funds. Therefore, we highlight how EK can act as a versatile and manifold tool for the sustainable treatment of contaminated soil.

\section{Acknowledgements}

This manuscript is the outcome of a workshop entitled "Environmental Electrokinetics: Advances in Soil and Water Treatment", held in Waterloo, Ontario, November 10-11, 2014. The workshop was a joint initiative of the Ecohydrology Research Group of University of Waterloo, Geosyntec Consultants and the Geosciences Research Entity (LOG) of Université de Lille - Sciences et Technologies. It was supported by grants from the France-Canada Research Fund (FCRF) and the National Science and Engineering Council (NSERC) Engage Program, and sponsored by Geosyntec and the Faculty of Science and the Water Institute of the University of Waterloo.

\section{References}

Aboughalma, H., Bi, R., Schlaak, M., 2008. Electrokinetic enhancement on phytoremediation in Zn, $\mathrm{Pb}, \mathrm{Cu}$ and $\mathrm{Cd}$ contaminated soil using potato plants. J. Environ. Sci. Health. A. Tox. Hazard. Subst. Environ. Eng. 43, 926-33. doi:10.1080/10934520801974459

Acar, Y.B., Alshawabkeh, A.N., 1993. The principles of Electrokinetics. Env. Sci Technol 27, 1-5. Acar, Y.B., Gale, R.J., Alshawabkeh, A.N., Marks, R.E., Puppala, S., Bricka, M., Parker, R., 1995. Electrokinetic remediation: Basics and technology status. J. Hazard. Mater. 40, 117-137. doi:10.1016/0304-3894(94)00066-P

Adamson, L.G., Chilingar, G. V., Beeson, C.M., Armstrong, R.A., 1966. Electrokinetic dewatering, consolidation and stabilization of soils. Eng. Geol. 1, 291-304. doi:10.1016/00137952(66)90011-1 
Al Shalabi, E.W., Ghosh, B., Haroun, M., Pamukcu, S., 2012. The Application of Direct Current Potential to Enhancing Waterflood Recovery Efficiency. Pet. Sci. Technol. 30, 2160-2168. doi:10.1080/10916466.2010.547902

Alcántara, M.T., Gómez, J., Pazos, M., Sanromán, M.A., 2012. Electrokinetic remediation of lead and phenanthrene polluted soils. Geoderma 173-174, 128-133. doi:10.1016/j.geoderma.2011.12.009

Ali, H., Khan, E., Sajad, M.A., 2013. Phytoremediation of heavy metals--concepts and applications. Chemosphere 91, 869-81. doi:10.1016/j.chemosphere.2013.01.075

Alshawabkeh, A.N., 2009. Electrokinetic Soil Remediation: Challenges and Opportunities. Sep. Sci. Technol. 44, 2171-2187.

Alshawabkeh, A.N., Acar, Y.B., 1992. Removal of contaminants from soils by electrokinetics: A theoretical treatise. J. Environ. Sci. Heal. . Part A Environ. Sci. Eng. Toxicol. 27, 1835-1861. doi:10.1080/10934529209375828

Amba, S.A., Chilingar, G.V., Beeson, C.M., 1964. Use of Direct Electrical Current for Increasing the Flow Rate of Reservoir Fluids During Petroleum Recovery. J. Can. Pet. Technol. 3, 8-14. doi:10.2118/64-01-02

Bai, R., Sutanto, M., 2002. The practice and challenges of solid waste management in Singapore. Waste Manag. 22, 557-567. doi:10.1016/S0956-053X(02)00014-4

Benner, S.G., Blowes, D.W., Ptacek, C.J., Mayer, K.U., 2002. Rates of sulfate reduction and metal sulfide precipitation in a permeable reactive barrier. Appl. Geochemistry 17, 301-320. doi:10.1016/S0883-2927(01)00084-1

Bennett, P., He, F., Zhao, D., Aiken, B., Feldman, L., 2010. In situ testing of metallic iron nanoparticle mobility and reactivity in a shallow granular aquifer. J. Contam. Hydrol. 116, 35-46. doi:10.1016/j.jconhyd.2010.05.006

Bolan, N., Kunhikrishnan, A., Thangarajan, R., Kumpiene, J., Park, J., Makino, T., Kirkham, M.B., Scheckel, K., 2014. Remediation of heavy metal(loid)s contaminated soils--to mobilize or to immobilize? J. Hazard. Mater. 266, 141-66. doi:10.1016/j.jhazmat.2013.12.018

Boparai, H.K., Joseph, M., O'Carroll, D.M., 2011. Kinetics and thermodynamics of cadmium ion removal by adsorption onto nano zerovalent iron particles. J. Hazard. Mater. 186, 458-65. doi:10.1016/j.jhazmat.2010.11.029

Brosky, R.T., Pamukcu, S., 2013. Role of DDL processes during electrolytic reduction of Cu(II) in a low oxygen environment. J. Hazard. Mater. 262, 878-82. doi:10.1016/j.jhazmat.2013.09.032

Callender, E., Rice, K.C., 2000. The Urban Environmental Gradient: Anthropogenic Influences on the 
Spatial and Temporal Distributions of Lead and Zinc in Sediments. Environ. Sci. Technol. 34, 232-238. doi:10.1021/es990380s

Cameselle, C., Chirakkara, R.A., Reddy, K.R., 2013a. Electrokinetic-enhanced phytoremediation of soils: status and opportunities. Chemosphere 93, 626-36. doi:10.1016/j.chemosphere.2013.06.029

Cameselle, C., Chirakkara, R.A., Reddy, K.R., 2013b. Chemosphere Electrokinetic-enhanced phytoremediation of soils : Status and opportunities. Chemosphere 93, 626-636. doi:10.1016/j.chemosphere.2013.06.029

Cameselle, C., Reddy, K.R., 2012. Development and enhancement of electro-osmotic flow for the removal of contaminants from soils. Electrochim. Acta 86, 10-22. doi:10.1016/j.electacta.2012.06.121

Casagrande, L., 1949. Electro-osmosis in soils. Geotechnique 1, 159-177.

Chaney, R.L., Malik, M., Li, Y.M., Brown, S.L., Brewer, E.P., Angle, J.S., Baker, A.J., 1997. Phytoremediation of soil metals. Curr. Opin. Biotechnol. 8, 279-284. doi:10.1016/S09581669(97)80004-3

Chilingar, G. V., El-Nassir, A., Stevens, R.G., 1968. Effect of Direct Electrical Current on Permeability of Sandstone Cores. J. Pet. Technol. 22, 830-836. doi:10.2118/2332-PA

Chowdhury, A.I.A., O'Carroll, D.M., Xu, Y., Sleep, B.E., 2012. Electrophoresis enhanced transport of nano-scale zero valent iron. Adv. Water Resour. 40, 71-82. doi:10.1016/j.advwatres.2012.01.014

Chung, H.I., Lee, M., 2007. A new method for remedial treatment of contaminated clayey soils by electrokinetics coupled with permeable reactive barriers. Electrochim. Acta 52, 3427-3431. doi:10.1016/j.electacta.2006.08.074

Cundy, A.B., Hopkinson, L.J., 2010. Electrokinetic soil remediation and engineering.

DeFlaun, M.F., Condee, C.W., 1997. Electrokinetic transport of bacteria. J. Hazard. Mater. 55, 263277. doi:10.1016/S0304-3894(97)00023-X

Dresel, P.E., Wellman, D.M., Cantrell, K.J., Truex, M.J., 2011. Review: Technical and policy challenges in deep vadose zone remediation of metals and radionuclides. Environ. Sci. Technol. 45, 420716. doi:10.1021/es101211t

EEA, 2009. Diverting waste from landfill - Effectiveness of waste management policies in the European Union. Copenhagen, Denmark.

Elliott, D.W., Zhang, W., 2001. Field Assessment of Nanoscale Bimetallic Particles for Groundwater Treatment. Environ. Sci. Technol. 35, 4922-4926. doi:10.1021/es0108584 
FAO, 2003. Groundwater Management - The search for practical approaches. Rome.

Ferrarese, E., Andreottola, G., Oprea, I.A., 2008. Remediation of PAH-contaminated sediments by chemical oxidation. J. Hazard. Mater. 152, 128-39. doi:10.1016/j.jhazmat.2007.06.080

Gent, D.B., Bricka, R.M., Alshawabkeh, A.N., Larson, S.L., Fabian, G., Granade, S., 2004. Bench- and field-scale evaluation of chromium and cadmium extraction by electrokinetics. J. Hazard. Mater. 110, 53-62. doi:10.1016/j.jhazmat.2004.02.036

Ghazanfari, E., Pamukcu, S., 2014. Mathematical Modeling of Electrokinetic Transport and Enhanced Oil Recovery in Porous Geo-Medi, in: Chilingar, G. V., Haroun, M. (Eds.), Electrokinetics for Petroleum and Environmental Engineers. John Wiley \& Sons, Inc., Hoboken, NJ, USA, pp. 177236. doi:10.1002/9781118842805

Ghazanfari, E., Pamukcu, S., Pervizpour, M., Karpyn, Z., 2014. Investigation of Generalized Relative Permeability Coefficients for Electrically Assisted Oil Recovery in Oil Formations. Transp. Porous Media 105, 235-253. doi:10.1007/s11242-014-0368-6

Ghazanfari, E., Shrestha, R.A., Miroshnik, A., Pamukcu, S., 2012. Electrically assisted liquid hydrocarbon transport in porous media. Electrochim. Acta 86, 185-191. doi:10.1016/j.electacta.2012.04.077

Ghosh, B., Shalabi, E.W. Al, Haroun, M., 2012. The Effect of DC Electrical Potential on Enhancing Sandstone Reservoir Permeability and Oil Recovery. Pet. Sci. Technol. 30, 2148-2159. doi:10.1080/10916466.2010.551233

Gill, R.T., Harbottle, M.J., Smith, J.W.N., Thornton, S.F., 2014. Electrokinetic-enhanced bioremediation of organic contaminants: A review of processes and environmental applications. Chemosphere 107, 31-42. doi:10.1016/j.chemosphere.2014.03.019

Giuliano, G., Carone, G., Corazza, A., 1998. Map of Pollution of Groundwater Used for Drinking Water Supply - The BIAS Project. Rome, Italy. doi:GNDCI Publication No. 1875

Godfray, H.C.J., Beddington, J.R., Crute, I.R., Haddad, L., Lawrence, D., Muir, J.F., Pretty, J., Robinson, S., Thomas, S.M., Toulmin, C., 2010. Food security: the challenge of feeding 9 billion people. Science 327, 812-8. doi:10.1126/science.1185383

Gomes, H.I., Dias-Ferreira, C., Ribeiro, A.B., Pamukcu, S., 2013. Enhanced Transport and Transformation of Zerovalent Nanoiron in Clay Using Direct Electric Current. Water, Air, Soil Pollut. 224, 1710. doi:10.1007/s11270-013-1710-2

Gomes, H.I., Ottosen, L.M., Ribeiro, A.B., Dias-Ferreira, C., 2015. Treatment of a suspension of PCB contaminated soil using iron nanoparticles and electric current. J. Environ. Manage. 151, 5505. doi:10.1016/j.jenvman.2015.01.015 
Guedes, P., Couto, N., Ottosen, L.M., Ribeiro, A.B., 2014. Phosphorus recovery from sewage sludge ash through an electrodialytic process. Waste Manag. 34, 886-92. doi:10.1016/j.wasman.2014.02.021

Guerin, T.F., 1999. Bioremediation of phenols and polycyclic aromatic hydrocarbons in creosote contaminated soil using ex-situ landtreatment. J. Hazard. Mater. 65, 305-315.

Hadley, P., Ellis, D., 2009. Sustainable Remediation White Paper-Integrating Sustainable Principles, Practices, and Metrics Into Remediation Projects. Remediation. doi:DOI: 10.1002/rem.20210

Hansen, H.K., Ottosen, L.M., Kliem, B.K., Villumsen, A., 1997. Electrodialytic remediation of soils polluted with $\mathrm{Cu}, \mathrm{Cr}, \mathrm{Hg}, \mathrm{Pb}$ and $\mathrm{Zn}$. J. Chem. Technol. Biotechnol. 70, 67-73.

Haroun, M.R., Chilingar, G. V., Pamukcu, S., Wittle, J.K., Belhaj, H., Al Bloushi, M.N., 2013. Optimizing Electroosmotic Flow Potential for Electrically Enhanced Oil Recovery (EEORTM) in Carbonate Rock formations of Abu Dhabi Based on Rock Properties and Composition, in: International Petroleum Technology Conference. International Petroleum Technology Conference. doi:10.2523/IPTC-13812-MS

He, F., Zhao, D., Paul, C., 2010. Field assessment of carboxymethyl cellulose stabilized iron nanoparticles for in situ destruction of chlorinated solvents in source zones. Water Res. 44, 2360-70. doi:10.1016/j.watres.2009.12.041

Henn, K.W., Waddill, D.W., 2006. Utilization of nanoscale zero-valent iron for source remediationA case study. Remediat. J. 16, 57-77. doi:10.1002/rem.20081

Higgins, T.E., Halloran, A.R., Petura, J.C., 2008. Traditional and innovative treatment methods for Cr(VI) in soil. Soil Sediment Contam. 6, 767-797.

Ho, S. V., Sheridan, P.W., Athmer, C.J., Heitkamp, M.A., Brackin, J.M., Weber, D., Brodsky, P.H., 1995. Integrated in situ soil remediation technology: The Lasagna process. Environ. Sci. Technol. 29, 2528-2534.

Huang, Y.-C., Cheng, Y.-W., 2012. Electrokinetic-enhanced nanoscale iron reactive barrier of trichloroethylene solubilized by Triton X-100 from groundwater. Electrochim. Acta 86, 177184. doi:10.1016/j.electacta.2012.03.048

Innocenti, I., Verginelli, I., Massetti, F., Piscitelli, D., Gavasci, R., Baciocchi, R., 2014. Pilot-scale ISCO treatment of a MtBE contaminated site using a Fenton-like process. Sci. Total Environ. 485486, 726-38. doi:10.1016/j.scitotenv.2014.01.062

Isosaari, P., Piskonen, R., Ojala, P., Voipio, S., Eilola, K., Lehmus, E., Itävaara, M., 2007. Integration of electrokinetics and chemical oxidation for the remediation of creosote-contaminated clay. J. 
Hazard. Mater. 144, 538-48. doi:10.1016/j.jhazmat.2006.10.068

ITRC, 2001. Technical and Regulatory Guidance for In Situ Chemical Oxidation of Contaminated Soil and Groundwater. Baton Rouge, LA.

ITRC, 2000. Dense Non-Aqueous Phase Liquids (DNAPLs): Review of Emerging Characterization and Remediation Technologies.

ITRC (Interstate Technology Regulatory Council), 2011. Technical/Regulatory Guidance Green and Sustainable Remediation: A Practical Framework Prepared by The Interstate Technology \&amp; Regulatory Council Green and Sustainable Remediation Team.

Jensen, P.E., Ottosen, L.M., Ferreira, C., 2007. Electrodialytic remediation of soil fines $(<63 \mu \mathrm{m})$ in suspension-Influence of current strength and L/S. Electrochim. Acta 52, 3412-3419. doi:10.1016/j.electacta.2006.03.116

Johnson, R.L., Nurmi, J.T., O’Brien Johnson, G.S., Fan, D., O’Brien Johnson, R.L., Shi, Z., Salter-Blanc, A.J., Tratnyek, P.G., Lowry, G. V, 2013. Field-scale transport and transformation of carboxymethylcellulose-stabilized nano zero-valent iron. Environ. Sci. Technol. 47, 1573-80. doi:10.1021/es304564q

Kamath, R., Rentz, J.A., Schnoor, J.L., Alvarez, P.J.J., 2004. Phytoremediation of hydrocarboncontaminated soils: principles and applications, in: Vazquez-Duhalt, R., Quintero-Ramirez, R. (Eds.), Studies in Surface Science and Catalysis 151. Elsevier B.V., pp. 447-478.

Keykha, H.A., Huat, B.B.K., Asadi, A., 2014. Electrokinetic Stabilization of Soft Soil Using CarbonateProducing Bacteria. Geotech. Geol. Eng. 32, 739-747. doi:10.1007/s10706-014-9753-8

Kim, K.-H., Kim, S.-O., Lee, C.-W., Lee, M.-H., Kim, K.-W., 2003. Electrokinetic Processing for the Removal of Radionuclides in Soils. Sep. Sci. Technol. 38, 2137-2163. doi:10.1081/SS120021617

Koch, A., McBratney, A., Adams, M., Field, D., Hill, R., Crawford, J., Minasny, B., Lal, R., Abbott, L., O’Donnell, A., Angers, D., Baldock, J., Barbier, E., Binkley, D., Parton, W., Wall, D.H., Bird, M., Bouma, J., Chenu, C., Flora, C.B., Goulding, K., Grunwald, S., Hempel, J., Jastrow, J., Lehmann, J., Lorenz, K., Morgan, C.L., Rice, C.W., Whitehead, D., Young, I., Zimmermann, M., 2013. Soil Security: Solving the Global Soil Crisis. Glob. Policy 4, 434-441. doi:10.1111/1758-5899.12096

Kocur, C.M., Chowdhury, A.I., Sakulchaicharoen, N., Boparai, H.K., Weber, K.P., Sharma, P., Krol, M.M., Austrins, L., Peace, C., Sleep, B.E., O'Carroll, D.M., 2014. Characterization of nZVI mobility in a field scale test. Environ. Sci. Technol. 48, 2862-9. doi:10.1021/es4044209

Kocur, C.M., O'Carroll, D.M., Sleep, B.E., 2013. Impact of nZVI stability on mobility in porous media. J. Contam. Hydrol. 145, 17-25. doi:10.1016/j.jconhyd.2012.11.001 
Krishna R. Reddy, M.R.K., 2007. Electrokinetic delivery of nanoscale iron particles for insitu remediation of pentachlorophenol-contaminated soils, in: Proceedings of the International Symposium on Geo-Environmental Engineering for Sustainable Development. Proceedings of the International Symposium on Geo-Environmental Engineering for Sustainable Development.

Krug, T., O’Hara, S., Watling, M., 2010. Emulsified Zero-Valent Nano-Scale Iron Treatment of Chlorinated Solvent DNAPL Source Areas. Arlington, VA.

Kubiak, J.J., Khankhane, P.J., Kleingeld, P.J., Lima, A.T., 2012. An attempt to electrically enhance phytoremediation of arsenic contaminated water. Chemosphere 87, 259-264.

Laethem, F. Van, Legrand, J., 1993. Impact sur l'environnement des remblais polluants de l'autoroute A22 au nord de Lille. Recherche de solutions. Bull. liaison des Lab. des Ponts Chaussees 188, 59-66.

Lageman, R., 1993. Electroreclamation. Environ. Sci. Technol. 27, 2648-2650.

Lageman, R., Godschalk, M.S., 2007. Electro-bioreclamation. A combination of in situ remediation techniques proves successful at a site in Zeist, the Netherlands. Electrochim. Acta 52, 34493453.

Liebeg, E.W., Cutright, T.J., 1999. The investigation of enhanced bioremediation through the addition of macro and micro nutrients in a PAH contaminated soil. Int. Biodeterior. Biodegradation 44, 55-64. doi:10.1016/S0964-8305(99)00060-8

Lima, A.T., Kleingeld, P.J., Heister, K., Loch, J.P.G., 2012a. In situ electro-osmotic cleanup of tar contaminated soil - removal of PAHs. Electrochim. Acta 86, 142-147.

Lima, A.T., Kleingeld, P.J., Heister, K., Loch, J.P.G., 2011. Removal of PAHs from contaminated clayey soil by means of electro-osmosis. Sep. Purif. Technol. 79, 221-229.

Lima, A.T., Loch, J.P.G., Kleingeld, P.J., 2010. Bentonite electrical conductivity: a model based on series-parallel transport. J. Appl. Electrochem. 40, 1061-1068. doi:10.1007/s10800-0090060-7

Lima, A.T., Ottosen, L.M., Heister, K., Loch, J.P.G., 2012b. Assessing PAH removal from clayey soil by means of electro-osmosis and electrodialysis. Sci. Total Environ. 435-436, 1-6. doi:10.1016/j.scitotenv.2012.07.010

Linley, S., Liu, Y., Ptacek, C.J., Blowes, D.W., Gu, F.X., 2014. Recyclable graphene oxide-supported titanium dioxide photocatalysts with tunable properties. ACS Appl. Mater. Interfaces 6, 465868. doi:10.1021/am4039272

Lockhart, N.C., Stickland, R.E., 1984. Dewatering coal washery tailings ponds by electroosmosis. 
Powder Technol. 40, 215-221.

López-Vizcaíno, R., Risco, C., Isidro, J., Rodrigo, S., Saez, C., Cañizares, P., Navarro, V., Rodrigo, M.A., 2017. Scale-up of the electrokinetic fence technology for the removal of pesticides. Part II: Does size matter for removal of herbicides? Chemosphere 166, 549-555. doi:10.1016/j.chemosphere.2016.09.114

Luo, Q., Wang, H., Zhang, X., Fan, X., Qian, Y., 2006. In situ bioelectrokinetic remediation of phenolcontaminated soil by use of an electrode matrix and a rotational operation mode. Chemosphere 64, 415-22. doi:10.1016/j.chemosphere.2005.11.064

Macdonald, R.W., Barrie, L.A., Bidleman, T.F., Diamond, M.L., Gregor, D.J., Semkin, R.G., Strachan, W.M.J., Li, Y.F., Wania, F., Alaee, M., Alexeeva, L.B., Backus, S.M., Bailey, R., Bewers, J.M., Gobeil, C., Halsall, C.J., Harner, T., Hoff, J.T., Jantunen, L.M.M., Lockhart, W.L., Mackay, D., Muir, D.C.G., Pudykiewicz, J., Reimer, K.J., Smith, J.N., Stern, G.., Schroeder, W.H., Wagemann, R., Yunker, M.B., 2000. Contaminants in the Canadian Arctic: 5 years of progress in understanding sources, occurrence and pathways. Sci. Total Environ. 254, 93-234. doi:10.1016/S00489697(00)00434-4

Maes, N., Moors, H., Dierckx, A., De Cannière, P., Put, M., 1999. The assessment of electromigration as a new technique to study diffusion of radionuclides in clayey soils. J. Contam. Hydrol. 36, 231247. doi:10.1016/S0169-7722(98)00146-6

Mao, X., Wang, J., Ciblak, A., Cox, E.E., Riis, C., Terkelsen, M., Gent, D.B., Alshawabkeh, A.N., 2012. Electrokinetic-enhanced bioaugmentation for remediation of chlorinated solvents contaminated clay. J. Hazard. Mater. 213-214, 311-7. doi:10.1016/j.jhazmat.2012.02.001

Margat, J., 2008. Les Eaux Souterraines dans le Monde. Ed. UNESCO/BRGM(Bureau de Recherches Géologiques et Minières).

McBratney, A., Field, D.J., Koch, A., 2014. The dimensions of soil security. Geoderma 213, 203-213. doi:10.1016/j.geoderma.2013.08.013

McCutcheon, S.C., Schnoor, J.L., 2004. Phytoremediation: Transformation and Control of Contaminants. John Wiley \& Sons.

Mena, E., Villaseñor, J., Rodrigo, M.A., Cañizares, P., 2016. Electrokinetic remediation of soil polluted with insoluble organics using biological permeable reactive barriers: Effect of periodic polarity reversal and voltage gradient. Chem. Eng. J. 299, 30-36. doi:10.1016/j.cej.2016.04.049

Merkx, O.K., Loch, J.P.G., Lima, A.T., Dijk, J.A., Kreuk, J.F., Kleingeld, P.J., 2013. The Effectiveness of Electro-Remediation of Aged, Metal-Contaminated Sediment in Relation to Sequential Extraction of Metals. Water, Air, Soil Pollut. 224, 1-12. doi:10.1007/s11270-013-1667-1 
Meuser, H., 2012. Soil Remediation and Rehabilitation: Treatment of Contaminated and Disturbed Land (Google eBook). Springer.

Mitchell, J.K., 1993. Fundamentals of Soil Behavior. John Wiley \& Sons, New York.

Moon, J.-W., Moon, H.-S., Kim, H., Roh, Y., 2005. Remediation of TCE-contaminated groundwater using zero valent iron and direct current: experimental results and electron competition model. Environ. Geol. 48, 805-817. doi:10.1007/s00254-005-0023-1

Moyne, C., Murad, M.A., 2002. Electro-chemo-mechanical couplings in swelling clays derived from a micro/macro-homogenization procedure. Int. J. Solids Struct. 39, 6159-6190. doi:10.1016/S0020-7683(02)00461-4

Nieto Castillo, A., García-Delgado, R.A., Cala Rivero, V., 2012. Electrokinetic treatment of soils contaminated by tannery waste. Electrochim. Acta 86, 110-114. doi:10.1016/j.electacta.2012.04.132

Niqui-Arroyo, J.-L., Bueno-Montes, M., Posada-Baquero, R., Ortega-Calvo, J.-J., 2006. Electrokinetic enhancement of phenanthrene biodegradation in creosote-polluted clay soil. Environ. Pollut. 142, 326-332. doi:10.1016/j.envpol.2005.10.007

Niqui-Arroyo, J.-L., Ortega-Calvo, J.-J., 2007. Integrating biodegradation and electroosmosis for the enhanced removal of polycyclic aromatic hydrocarbons from creosote-polluted soils. J. Environ. Qual. 36, 1444-1451.

Nystroem, G.M., Ottosen, L.M., Villumsen, A., 2005. Electrodialytic removal of Cu, Zn, Pb, and Cd from harbor sediment: Influence of changing experimental conditions. Environ. Sci. Technol. 39, 2906-2911.

O’Mahony, M.M., Dobson, A.D.W., Barnes, J.D., Singleton, I., 2006. The use of ozone in the remediation of polycyclic aromatic hydrocarbon contaminated soil. Chemosphere 63, 307-14. doi:10.1016/j.chemosphere.2005.07.018

Ottosen, L., Rorig-Dalgaard, I., 2009. Method and device for removing an ionic impurity from building structures. WO2009124890.

Ottosen, L.M., Hansen, H.K., 1992. Electrokinetic cleaning of heavy metals polluted soil. Intern. Report, Fys. Inst. Geol. og Geotek.

Ottosen, L.M., Hansen, H.K., Hansen, C.B., 2000. Water splitting at ion-exchange membranes and potential differences in soil during electrodialytic soil remediation. J. Appl. Electrochem. 30, 1199-1207.

Ottosen, L.M., Hansen, H.K., Laursen, S., Villumsen, A., 1997. Electrodialytic remediation of soil polluted with copper from wood preservation industry. Environ. Sci. Technol. 31, 1711-1715. 
Ottosen, L.M., Jensen, P.E., Kirkelund, G.M., Dias-Ferreira, C., Hansen, H.K., 2012. Electrodialytic remediation of heavy metal polluted soil - Treatment of water saturated or suspended soil, in: Chemical Engineering Transactions. Italian Association of Chemical Engineering - AIDIC, pp. 103-108. doi:10.3303/CET1228018

Ouhadi, V.R., Yong, R.N., Shariatmadari, N., Saeidijam, S., Goodarzi, A.R., Safari-Zanjani, M., 2010. Impact of carbonate on the efficiency of heavy metal removal from kaolinite soil by the electrokinetic soil remediation method. J. Hazard. Mater. 173, 87-94. doi:10.1016/j.jhazmat.2009.08.052

Paillat, T., Moreau, E., Grimaud, P.O., Touchard, G., 2000. Electrokinetic phenomena in porous media applied to soil decontamination. IEEE Trans. Dielectr. Electr. Insul. 7, 693-704. doi:10.1109/94.879363

Pamukcu, S., 2009. Electrochemical Transport and Transformations, in: Reddy, K.R., Cameselle, C. (Eds.), Electrochemical Remediation Technologies for Polluted Soils, Sediments and Groundwater. John Wiley \& Sons, Inc., Hoboken, NJ, USA, pp. 29-65. doi:10.1002/9780470523650

Pamukcu, S., 1994. Electrokinetic removal of coal tar constituents from contaminated soils. Final Report, EPRI TR-103320, Proj. 2879-21.

Pamukcu, S., Shrestha, R.A., Ribeiro, A.B., Mateus, E.P., 2016. Electrically induced displacement transport of immiscible oil in saline sediments. J. Hazard. Mater. 313, 185-92. doi:10.1016/j.jhazmat.2016.04.005

Pamukcu, S., Weeks, A., Wittle, J.K., 2004. Enhanced Reduction of Cr(VI) by Direct Electric Current in a Comminated Clay. Environ. Sci. Technol. 38, 1236-1241.

Pamukcu, S., Weeks, A., Wittle, J.K., 1997. Electrochemical extraction and stabilization of selected inorganic species in porous media. J. Hazard. Mater. 55, 305-318.

Pamukcu, S., Wittle, J.K., 1992. Electrokinetic removal of selected heavy metals from soil. Environ. Prog. 11, 241-250.

Pazos, M., Rosales, E., Alcántara, T., Gómez, J., Sanromán, M.A., 2010. Decontamination of soils containing PAHs by electroremediation: a review. J. Hazard. Mater. 177, 1-11. doi:10.1016/j.jhazmat.2009.11.055

Petri, B.G., Watts, R.J., Teel, A.L., Huling, S.G., Brown, R.A., 2011. Fundamentals of ISCO Using Hydrogen Peroxide, in: Siegrist, R.L. (Ed.), In Situ Chemical Oxidation for Groundwater Remediation. Springer, Berlin, Heidelberg, pp. 33-88. doi:10.1007/978-1-4419-7826-4_2 Pilon-Smits, E., 2005. Phytoremediation. Annu. Rev. Plant Biol. 56, 15-39. 
doi:10.1146/annurev.arplant.56.032604.144214

Ramírez, E.M., Jiménez, C.S., Camacho, J.V., Rodrigo, M.A.R., Cañizares, P., 2015. Feasibility Of Coupling Permeable Bio-Barriers And Electrokinetics For The Treatment Of Diesel Hydrocarbons Polluted Soils. Electrochim. Acta. doi:10.1016/j.electacta.2015.02.201

Reddy, K.R., 2010. Technical challenges to in-situ remediation of polluted sites. Geotech. Geol. Eng. $28,211-221$.

Reddy, K.R., Cameselle, C., 2009. Electrochemical Remediation Technologies for Polluted Soils, Sediments and Groundwater. John Wiley \& Sons.

Reddy, K.R., Darko-Kagya, K., Al-Hamdan, A.Z., 2011. Electrokinetic remediation of pentachlorophenol contaminated clay soil. Water. Air. Soil Pollut. 221, 35-44.

Reuss, F.F., 1809. Sur un nouvel effet de l'électricité glavanique. Mémoires la Soc. Impériale des Nat. Moscou 2, 327-337.

Reynolds, D.A., 2015. In situ remediation of soils and ground water containing organic contaminants. US9004816 B2.

Ribeiro, A.B., Rodrí́guez-Maroto, J.M., Mateus, E.P., Gomes, H., 2005. Removal of organic contaminants from soils by an electrokinetic process: The case of atrazine. Experimental and modeling. Chemosphere 59, 1229-1239.

Riis, C., Bymose, M., Cox, E., Wang, J., Gent, D., Terkelsen, M., 2012. Succesfull pilot test of electrokinetic enhanced bioremediation (EK-BIO) as an innovative remedial approach for PCE DNAPL source area, in: NORDROCS 2012: 4th Nordic Joint Meeting on Remediation of Contaminated Sites, International Conference. Oslo, Norway, p. 4 pp.

Roach, N., Reddy, K.R., 2006. Electrokinetic delivery of permanganate into low-permeability soils. Int. J. Environ. Waste Manag. 1, 4-19.

Roh, Y., Lee, S.Y., Elless, M.P., Cho, K.S., 2000. Electro-enhanced remediation of radionuclidecontaminated groundwater using zero-valent iron. J. Environ. Sci. Heal. - Part A Toxic/Hazardous Subst. Environ. Eng. 35, 1043-1059.

Sa V. Ho, *, $†$, Christopher Athmer, †, P. Wayne Sheridan, †, B. Mason Hughes, $\dagger$, Robert Orth, †, David McKenzie, †, Philip H. Brodsky, †, Andrew M. Shapiro, キ, Timothy M. Sivavec, $\neq$, Joseph Salvo, ‡, Dale Schultz, §, Richard Landis, §, Ron Griffith, § and, Shoemaker§, S., 1999a. The Lasagna Technology for In Situ Soil Remediation. 2. Large Field Test. doi:10.1021/ES980414G Sa V. Ho, *,, Christopher Athmer, †, P. Wayne Sheridan, †, B. Mason Hughes, †, Robert Orth, †, David McKenzie, †, Philip H. Brodsky, †, Andrew Shapiro, ‡, Roy Thornton, ‡, Joseph Salvo, ‡, Dale Schultz, §, Richard Landis, §, Ron Griffith, § and, Shoemaker§, S., 1999b. The Lasagna 
Technology for In Situ Soil Remediation. 1. Small Field Test. doi:10.1021/ES980332S

Saichek, R.E., Reddy, K.R., 2005. Electrokinetically enhanced remediation of hydrophobic organic compounds in soils: A review. Crit. Rev. Environ. Sci. Technol. 35, 115-192.

Saichek, R.E., Reddy, K.R., 2004. Evaluation of surfactants/cosolvents for desorption/solubilization of phenanthrene in clayey soils. Int. J. Environ. Stud. 61, 587-604.

Saichek, R.E., Reddy, K.R., 2003. Effect of pH control at the anode for the electrokinetic removal of phenanthrene from kaolin soil. Chemosphere 51, 273-287.

Sakulchaicharoen, N., O'Carroll, D.M., Herrera, J.E., 2010. Enhanced stability and dechlorination activity of pre-synthesis stabilized nanoscale FePd particles. J. Contam. Hydrol. 118, 117-27. doi:10.1016/j.jconhyd.2010.09.004

Satapanajaru, T., Anurakpongsatorn, P., Pengthamkeerati, P., Boparai, H., 2008. Remediation of Atrazine-contaminated Soil and Water by Nano Zerovalent Iron. Water. Air. Soil Pollut. 192, 349-359. doi:10.1007/s11270-008-9661-8

Sayles, G.D., You, G., Wang, M., Kupferle, M.J., 1997. DDT, DDD, and DDE Dechlorination by ZeroValent Iron. Environ. Sci. Technol. 31, 3448-3454. doi:10.1021/es9701669

Schnarr, M., Truax, C., Farquhar, G., Hood, E., Gonullu, T., Stickney, B., 1998. Laboratory and controlled field experiments using potassium permanganate to remediate trichloroethylene and perchloroethylene DNAPLs in porous media. J. Contam. Hydrol. 29, 205-224. doi:10.1016/S0169-7722(97)00012-0

Schultz, D.S., 1997. Electroosmosis technology for soil remediation: laboratory results, field trial, and economic modeling. J. Hazard. Mater. 55, 81-91. doi:10.1016/S0304-3894(97)00014-9

Semple, K.T., Doick, K.J., Jones, K.C., Burauel, P., Craven, A., Harms, H., 2004. Peer Reviewed: Defining Bioavailability and Bioaccessibility of Contaminated Soil and Sediment is Complicated. Environ. Sci. Technol. 38, 228A-231A. doi:10.1021/es040548w

Seto, K.C., Fragkias, M., Güneralp, B., Reilly, M.K., 2011. A meta-analysis of global urban land expansion. PLoS One 6, e237-77. doi:10.1371/journal.pone.0023777

Shah, T., Burke, J., Villholth, K., Angelica, M., Custodio, E., Daibes, F., Hoogesteger, J., Giordano, M., Girman, J., van der Gun, J., Kendy, E., Kijne, J., Llamas, R., Masiyandama, M., Margat, J., Marin, L., Peck, J., Rozelle, S., Sharma, B., Vincent, L., Wang, J., 2007. Water for Food Water for Life, Water for Food Water for Life: A Comprehensive Assessment of Water Management in Agriculture. Routledge. doi:10.4324/9781849773799

Shalabi, E.W. Al, Haroun, M., Ghosh, B., Pamukcu, S., 2012. The Stimulation of Sandstone Reservoirs Using DC Potential. Pet. Sci. Technol. 30, 2137-2147. doi:10.1080/10916466.2010.551811 
Siegrist, R.L., Urynowicz, M.A., West, O.R., Crimi, M.L., Lowe, K.S., 2001. In-Situ Chemical Oxidation Using Permanganate. Batelle Press, Columbus, $\mathrm{OH}$.

Simons, R., 1984. Electric field effects on proton transfer between ionizable groups and water in ion exchange membranes. Electrochim. Acta 29, 151-158.

Song, H., Carraway, E.R., 2005. Reduction of Chlorinated Ethanes by Nanosized Zero-Valent Iron: Kinetics, Pathways, and Effects of Reaction Conditions. Environ. Sci. Technol. 39, 62376245. doi:10.1021/es048262e

Straube, W.L., Nestler, C.C., Hansen, L.D., Ringleberg, D., Pritchard, P.H., Jones-Meehan, J., 2003. Remediation of Polyaromatic Hydrocarbons (PAHs) through Landfarming with Biostimulation and Bioaugmentation. Acta Biotechnol. 23, 179-196. doi:10.1002/abio.200390025

Sturman, P.J., Stewart, P.S., Cunningham, A.B., Bouwer, E.J., Wolfram, J.H., 1995. Engineering scale-up of in situ bioremediation processes: a review. J. Contam. Hydrol. 19, 171-203. doi:10.1016/0169-7722(95)00017-P

Sun, T.R., Ottosen, L.M., Jensen, P.E., Kirkelund, G.M., 2012. Electrodialytic remediation of suspended soil--Comparison of two different soil fractions. J. Hazard. Mater. 203-204, 229-35. doi:10.1016/j.jhazmat.2011.12.006

Sun, T.R., Pamukcu, S., Ottosen, L.M., Wang, F., 2015. Electrochemically enhanced reduction of hexavalent chromium in contaminated clay: Kinetics, energy consumption, and application of pulse current. Chem. Eng. J. 262, 1099-1107. doi:10.1016/j.cej.2014.10.081

Suzuki, T., Moribe, M., Oyama, Y., Niinae, M., 2012. Mechanism of nitrate reduction by zero-valent iron: Equilibrium and kinetics studies. Chem. Eng. J. 183, 271-277. doi:10.1016/j.cej.2011.12.074

Tromp, K., Lima, A.T., Barendregt, A., Verhoeven, J.T., 2012. Retention of heavy metals and polyaromatic hydrocarbons from road water in a constructed wetland and the effect of de-icing. J. Hazard. Mater. 203-204, 290-8. doi:10.1016/j.jhazmat.2011.12.024

Tyagi, M., da Fonseca, M.M.R., de Carvalho, C.C.C.R., 2011. Bioaugmentation and biostimulation strategies to improve the effectiveness of bioremediation processes. Biodegradation 22, 23141. doi:10.1007/s10532-010-9394-4

United Nations, 2009. World Urbanization Prospects The 2009 Revision Highlights. New York. US EPA, 2014. Mid-Atlantic Brownfields \& Land Revitalization [WWW Document]. URL http://www.epa.gov/reg3hwmd/bf-lr/cleanupfs.html (accessed 9.17.15). USEPA, 2006. In-Situ Chemical Oxidation. Cincinnati, OH. Valdovinos, V., Monroy-Guzmán, F., Bustos, E., 2016. Electrokinetic removal of radionuclides 
contained in scintillation liquids absorbed in soil type Phaeozem. J. Environ. Radioact. 162, 8086. doi:10.1016/j.jenvrad.2016.05.017

Vidali, M., 2001. Bioremediation. An overview. Pure Appl. Chem. 73, 1163-1172. doi:10.1351/pac200173071163

Vieira dos Santos, E., Sáez, C., Cañizares, P., Martínez-Huitle, C.A., Rodrigo, M.A., 2017. Reversible electrokinetic adsorption barriers for the removal of atrazine and oxyfluorfen from spiked soils. J. Hazard. Mater. 322, 413-420. doi:10.1016/j.jhazmat.2016.10.032

Virkutyte, J., Sillanpaa, M., 2002. Electrokinetic soil remediation - critical overview. Sci. Total Environ. 289, 97-121.

Wang, C.-B., Zhang, W., 1997. Synthesizing Nanoscale Iron Particles for Rapid and Complete Dechlorination of TCE and PCBs. Environ. Sci. Technol. 31, 2154-2156. doi:10.1021/es970039c

Wei, Y.-T., Wu, S.-C., Chou, C.-M., Che, C.-H., Tsai, S.-M., Lien, H.-L., 2010. Influence of nanoscale zerovalent iron on geochemical properties of groundwater and vinyl chloride degradation: A field case study. Water Res. 44, 131-40. doi:10.1016/j.watres.2009.09.012

Weis, J.S., Weis, P., 2004. Metal uptake, transport and release by wetland plants: Implications for phytoremediation and restoration. Environ. Int. 30, 685-700.

Weng, C.-H., Lin, Y.-T., Lin, T.Y., Kao, C.M., 2007. Enhancement of electrokinetic remediation of hyper-Cr(VI) contaminated clay by zero-valent iron. J. Hazard. Mater. 149, 292-302. doi:10.1016/j.jhazmat.2007.03.076

Wick, A.F., Haus, N.W., Sukkariyah, B.F., Haering, K.C., Daniels, W.L., 2011. Remediation of PAHcontaminated soils and sediments: A literature review. Blacksburg, VA.

Wick, L.Y., Mattle, P.A., Wattiau, P., Harms, H., 2004. Electrokinetic Transport of PAH-Degrading Bacteria in Model Aquifers and Soil. Environ. Sci. Technol. 38, 4596-4602. doi:10.1021/es0354420

Wittle, J.K., Bell, C.W., 2002. Electrochemical system and method for rendering contaminated electrically conductive material nonhazardous. US 6486376 B2.

Wittle, J.K., Hill, D.G., Chilingar, G. V., 2011. Direct Electric Current Oil Recovery (EEOR)-A New Approach to Enhancing Oil Production. Energy Sources, Part A Recover. Util. Environ. Eff. 33, 805-822. doi:10.1080/15567036.2010.514843

Yang, G.C.C., Chen, M.-C., Yeh, C.-F., 2011. Dewatering of a biological industrial sludge by electrokinetics-assisted filter press. Sep. Purif. Technol. 79, 177-182. doi:10.1016/j.seppur.2011.02.012 
922 Yang, G.C.C., Lee, H.-L., 2005. Chemical reduction of nitrate by nanosized iron: kinetics and

923 pathways. Water Res. 39, 884-94. doi:10.1016/j.watres.2004.11.030

924 Yang, L., Nakhla, G., Bassi, A., 2005. Electro-kinetic dewatering of oily sludges. J. Hazard. Mater. 125, $925 \quad 130-140$.

926 Yeung, A.T., 2011. Milestone developments, myths, and future directions of electrokinetic

927 remediation. Sep. Purif. Technol. 79, 124-132. doi:10.1016/j.seppur.2011.01.022

928 Yongming, H., Peixuan, D., Junji, C., Posmentier, E.S., 2006. Multivariate analysis of heavy metal 929 contamination in urban dusts of Xi'an, Central China. Sci. Total Environ. 355, 176-186.

930 Yukselen-Aksoy, Y., Reddy, K.R., 2012. Effect of soil composition on electrokinetically enhanced 931 persulfate oxidation of polychlorobiphenyls. Electrochim. Acta 86, 164-169.

932 doi:10.1016/j.electacta.2012.03.049

933 Zaporozec, A., 2002. Groundwater contamination inventory - A methodological guide. Madison.

934 Zhang, S., Zhang, J., Cheng, X., Mei, Y., Hu, C., Wang, M., Li, J., 2015. Electrokinetic remediation of soil 935 containing $\mathrm{Cr}(\mathrm{VI})$ by photovoltaic solar panels and a DC-DC converter. J. Chem. Technol.

936 Biotechnol. 90, 693-700. doi:10.1002/jctb.4359

937 Zhang, W., n.d. Nanoscale Iron Particles for Environmental Remediation: An Overview. J.

938 Nanoparticle Res. 5, 323-332. doi:10.1023/A:1025520116015

939 Zhou, M., Zhu, S., Yi, Y., Zhang, T., 2016. An electrokinetic/activated alumina permeable reactive 940 barrier-system for the treatment of fluorine-contaminated soil. Clean Technol. Environ. Policy 941 18, 2691-2699. doi:10.1007/s10098-016-1156-5

942

943 
944

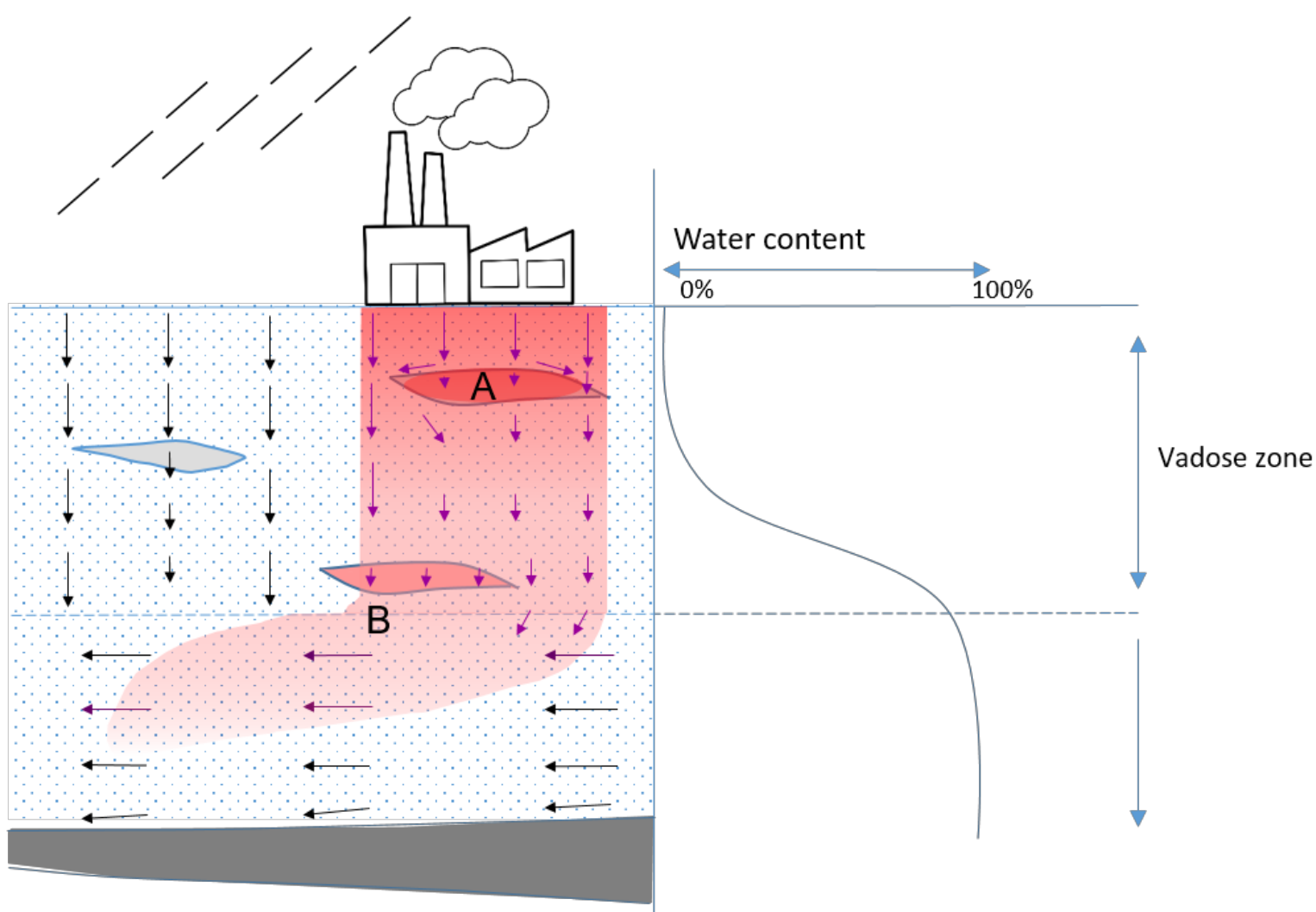

Legend:

$\begin{array}{lll}\text { Low permeability layer or lenses } & \text { Clay } & \text { Flow direction } \\ \text { Permeable layer } & \text { Contamination }\end{array}$

945

946

947

948

Figure 1 -Schematics of a plume. A-source pollution; B-plume migration 
Location of EK- enhanced treatment

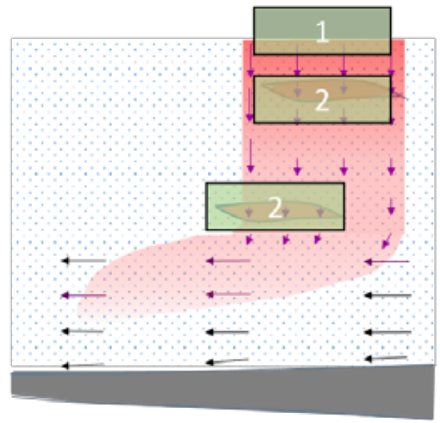

Clayey soil Sandy soil

949

950

951

952

953 954

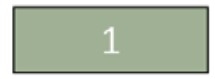

EK-Phyto

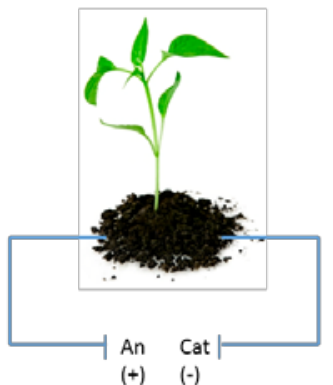

EO - electro-osmosis EP - electrophoresis EM - electromigration
EK-Bio, EK-ISCO, EK-Nano

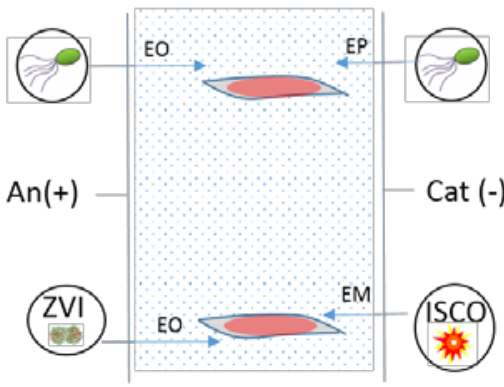

$\mathrm{ZVI}$ - Zero Valent Iron ISCO - In-Situ Chemical Oxidation

Figure 2 - Schematic representation of electrokinetically enhanced remediation. The left most scheme shows where, within the subsurface or underground, which EK-enhancement would be better suited. Scheme 1 (middle frame) represents the combination of EK with phytoremediation. Scheme 2 (right frame) summarizes how EK would enhance/transport/aid bioremediation, ISCO and nZVI applications. 
Table 1 - Summary of the main defining characteristics of soil remediation techniques, the main application challenges and how EK can overcome them

\begin{tabular}{|c|c|c|c|c|c|c|}
\hline & $\begin{array}{l}\text { In-Situ } \\
\text { Bioremediation }\end{array}$ & Phytoremediation & $\begin{array}{l}\text { Nano-scale Zero } \\
\text { Valent Iron (nZVI) }\end{array}$ & ISCO & Landfilling & $\begin{array}{l}\text { Thermal(Lebrón et al., } \\
\text { 2013; McGuire et al., } \\
\text { 2016) }\end{array}$ \\
\hline $\begin{array}{l}\text { Target } \\
\text { pollutants }\end{array}$ & $\begin{array}{l}\text { Organic contaminants } \\
\text { (chlorinated solvents, } \\
\text { BTEX and other } \\
\text { aromatic compounds, } \\
\text { pesticides); some } \\
\text { metals(Vidali, 2001) }\end{array}$ & $\begin{array}{l}\text { Metals, metalloids } \\
\text { (Ali et al., 2013) and } \\
\text { organic } \\
\text { contaminants } \\
\text { (Seeger et al., 2013) }\end{array}$ & $\begin{array}{l}\text { Organochlorines, } \\
\text { nitroaromatics, dyes, } \\
\text { phenols, heavy } \\
\text { metals, pesticides, } \\
\text { and anions } \\
\left(\text { e.g., } \mathrm{NO}_{3}^{-1} \text { ) }\right.\end{array}$ & $\begin{array}{l}\text { All oxidizable } \\
\text { pollutants like } \\
\text { organic pollutants } \\
\text { (petroleum } \\
\text { hydrocarbons, } \\
\text { organochlorines, } \\
\text { pesticides) and } \\
\text { metals(Boparai et } \\
\text { al., 2011; Nieto } \\
\text { Castillo et al., 2012) }\end{array}$ & $\begin{array}{l}\text { Metals, hazardous } \\
\text { contaminants } \\
\text { unamenable to in-situ } \\
\text { remediation }\end{array}$ & $\begin{array}{l}\text { Volatile organic } \\
\text { compounds }\end{array}$ \\
\hline $\begin{array}{l}\text { Energy } \\
\text { requirements }\end{array}$ & $\begin{array}{l}\text { Low; depends on } \\
\text { contaminant, bacteria, } \\
\text { and technique. } \\
\text { Laboratory scale } \\
\text { experiments prior to } \\
\text { field applications are } \\
\text { often required, as well } \\
\text { as treatability studies }\end{array}$ & $\begin{array}{l}\text { Low. Plants are } \\
\text { placed in-situ and } \\
\text { some maintenance } \\
\text { is required. } \\
\text { Harvesting and } \\
\text { replacement of } \\
\text { plants }\end{array}$ & $\begin{array}{l}\text { Low to moderate. It } \\
\text { requires pumping and } \\
\text { delivery of nano- } \\
\text { particles to pollutant }\end{array}$ & $\begin{array}{l}\text { Moderate to high; } \\
\text { higher than other in- } \\
\text { situ (non-thermal) } \\
\text { remediation } \\
\text { technologies. } \\
\text { Electricity } \\
\text { application from } \\
<0.22 \text { - } 44 \mathrm{kWh} / \mathrm{ton} \\
\text { of ozone activation; } \\
33.33 \mathrm{kWh} / \mathrm{m}^{3} \text { for } \\
\text { persulfate activation } \\
\text { (USEPA, 2006; Yan } \\
\text { et al.) }\end{array}$ & $\begin{array}{l}\text { Moderate to high. Mainly } \\
\text { for excavation and } \\
\text { transportation }\end{array}$ & $\begin{array}{l}\text { High. The approach } \\
\text { requires heating of } \\
\text { impacted soil and } \\
\text { groundwater to (at a } \\
\text { minimum) the boiling } \\
\text { point of water) }\end{array}$ \\
\hline Water usage & $\begin{array}{l}\text { Low to moderate; } \\
\text { depends on nutrient } \\
\text { requirements }\end{array}$ & $\begin{array}{l}\text { Low to moderate; } \\
\text { depends on } \\
\text { vegetative cover. }\end{array}$ & $\begin{array}{l}\text { Moderate. ZVI needs } \\
\text { to be diluted in water } \\
\text { (e.g. } 68 \mathrm{~m}^{3} \text { of water } \\
\text { with a concentration } \\
\text { of } 2 \mathrm{~g} / \mathrm{L} \text { of } \mathrm{nZVI}(\mathrm{US}\end{array}$ & $\begin{array}{l}\text { Moderate. Oxidant } \\
\text { needs to be diluted } \\
\text { in water (e.g. } 8 \text { - } \\
14.5 \mathrm{~m}^{3} \text { of water for } \\
\text { persulfate }\end{array}$ & $\begin{array}{l}\text { Low. Landfill leachate } \\
\text { needs to be treated, but } \\
\text { does not add to water } \\
\text { requirements }\end{array}$ & $\begin{array}{l}\text { Low. Water may be } \\
\text { used to increase } \\
\text { contact with the soil to }\end{array}$ \\
\hline
\end{tabular}




\begin{tabular}{|c|c|c|c|c|c|c|c|}
\hline & & & $\begin{array}{l}\text { Continued irrigation } \\
\text { is required }\end{array}$ & $\begin{array}{l}\text { EPA and USEPA, } \\
\text { 2000)). Intensive at } \\
\text { the beginning stages }\end{array}$ & $\begin{array}{l}\text { dilution(Yan et al.)). } \\
\text { Intensive at the } \\
\text { beginning stages }\end{array}$ & & $\begin{array}{l}\text { be treated or to cool } \\
\text { electrodes. }\end{array}$ \\
\hline \multicolumn{2}{|c|}{$\begin{array}{l}\text { Maintenance } \\
\text { requirements }\end{array}$} & $\begin{array}{l}\text { Low to moderate } \\
\text { (nutrient additions); } \\
\text { pH, oxygen content, } \\
\text { nutrient } \\
\text { regulation(Vidali, } \\
\text { 2001) }\end{array}$ & $\begin{array}{l}\text { Low to moderate. } \\
\text { Maintenance } \\
\text { requirements }\end{array}$ & Low & $\begin{array}{l}\text { Low to moderate } \\
\text { depending on } \\
\text { oxidant choice, } \\
\text { soil/site conditions }\end{array}$ & \begin{tabular}{|l|} 
Moderate; landfill \\
maintenance and \\
leachate management
\end{tabular} & Moderate. \\
\hline \multicolumn{2}{|c|}{ Duration } & $\begin{array}{l}\text { Long (can last years); } \\
\text { depends on } \\
\text { microorganisms, } \\
\text { contaminant } \\
\text { availability (US EPA } \\
\text { and USEPA, 2000), } \\
\text { and soil heterogeneity }\end{array}$ & $\begin{array}{l}\text { Long (up to } 30 \text { years } \\
\text { or more(Kamath et } \\
\text { al., 2004)) }\end{array}$ & $\begin{array}{l}\text { Short (depends on } \\
\text { transport of ZVI to } \\
\text { target area). However } \\
\text { recent studies suggest } \\
\text { that nZVI can } \\
\text { stimulate } \\
\text { bioremediation } \\
\text { (Kocur et al., 2015) }\end{array}$ & $\begin{array}{l}\text { Short to moderate. } \\
\text { Variable depending } \\
\text { on nature of } \\
\text { contaminant } \\
\text { (sorbed, free phase, } \\
\text { solubility, etc.) }\end{array}$ & $\begin{array}{l}\text { Long. Waste is deposited } \\
\text { in landfill, contamination } \\
\text { transference }\end{array}$ & $\begin{array}{l}\text { Short. Remediation } \\
\text { programs are often on } \\
\text { the order of weeks to } \\
\text { months. }\end{array}$ \\
\hline \multirow{2}{*}{$\begin{array}{l}\text { Distu } \\
\text { rban } \\
\text { ce of } \\
\text { the } \\
\text { subs } \\
\text { urfac } \\
\text { e }\end{array}$} & $\begin{array}{l}\text { Mech } \\
\text { anica } \\
\text { l }\end{array}$ & Low & Low & Low & Low & High & $\begin{array}{l}\text { Moderate. Potential for } \\
\text { changes to soil } \\
\text { structure. }\end{array}$ \\
\hline & $\begin{array}{l}\text { Biolo } \\
\text { gical/ } \\
\text { chem } \\
\text { ical }\end{array}$ & Moderate & Low & $\begin{array}{l}\text { Moderate. Change of } \\
\text { geochemical } \\
\text { conditions }\end{array}$ & $\begin{array}{l}\text { Moderate. Change of } \\
\text { geochemical } \\
\text { conditions }\end{array}$ & High & $\begin{array}{l}\text { Moderate. Biological } \\
\text { polishing following } \\
\text { thermal treatment has } \\
\text { been demonstrated as } \\
\text { effective }\end{array}$ \\
\hline \multicolumn{2}{|c|}{$\begin{array}{l}\text { Cost (all } \\
\text { values in } \\
\text { USD) }\end{array}$} & $\begin{array}{l}\text { Wide range of low to } \\
\text { high. From } \$ 30- \\
100 / \mathrm{m}^{3} \text { (aerobic } \\
\text { degradation field } \\
\text { demonstration); }\end{array}$ & $\begin{array}{l}\text { Low. } \$ 15-25 / \mathrm{m}^{3} \\
\text { (calculated based on } \\
\text { the treatment of } \\
\text { upper } 1 \mathrm{~m}\end{array}$ & $\begin{array}{l}\text { High. } \$ 255,000 \text { to } \\
\$ 1,400,000 \text { for } 2987 \\
\text { ha (numbers based on } \\
\text { a specific } \\
\text { site)(Gavaskar et al., }\end{array}$ & $\begin{array}{l}\text { Moderate. Median } \\
\text { cost of } \$ 123 / \mathrm{m}^{3} \\
\text { based on } 33 \text { case } \\
\text { studies (Krembs et } \\
\text { al., 2010) but can }\end{array}$ & $\begin{array}{l}\text { Low to moderate. } \\
\text { Landfill disposal costs } \\
\text { between } \$ 250-350 / \mathrm{m}^{3} \\
\text { (US EPA, 2014), and with } \\
\text { possible total costs }\end{array}$ & High. \\
\hline
\end{tabular}




\begin{tabular}{|c|c|c|c|c|c|c|}
\hline & $\begin{array}{l}\$ 323,000 \text { for a } \\
\text { specific site of } 480 \mathrm{~m}^{2} \text {, } \\
\text { (based on project } \\
\text { costs) (US EPA and } \\
\text { USEPA, 2000; USEPA } \\
\text { and US EPA, 1998) }\end{array}$ & $\begin{array}{l}\text { layer)(McCutcheon } \\
\text { and Schnoor, 2004) }\end{array}$ & $\begin{array}{l}\text { 2005). Nano-particles } \\
\text { cost is } \$ 50 / \mathrm{kg} \text { of nZVI }\end{array}$ & $\begin{array}{l}\text { amount to } \$ 527 / \mathrm{m}^{3} \\
\text { (Innocenti et al., } \\
2014 \text { ) }\end{array}$ & $\begin{array}{l}\text { (excavation, transport, } \\
\text { disposal, labour) } \\
\text { amounting to } \$ 650 / \mathrm{m}^{3} \\
\text { (personal } \\
\text { communication, } \\
\text { Geosyntec) }\end{array}$ & \\
\hline $\begin{array}{l}\text { Main } \\
\text { challenge }\end{array}$ & $\begin{array}{l}\text { Limited to } \\
\text { biodegradable } \\
\text { compounds, where } \\
\text { degradation products } \\
\text { may be more } \\
\text { persistent or toxic } \\
\text { than parent } \\
\text { compounds. Long } \\
\text { remediation times for } \\
\text { some compounds } \\
\text { (Singh and Ward, } \\
2004 \text { ) }\end{array}$ & $\begin{array}{l}\text { Long remediation } \\
\text { times. Address } \\
\text { contaminant mainly } \\
\text { at the relatively } \\
\text { shallow subsurface } \\
\text { (root zone) }\end{array}$ & $\begin{array}{l}\text { nZVI particles need to } \\
\text { be delivered to } \\
\text { contaminant zone. } \\
\text { Limited reactive } \\
\text { lifetime of nZVI }\end{array}$ & $\begin{array}{l}\text { Slow mass transfer, } \\
\text { transport, and less } \\
\text { control over oxidant } \\
\text { due to limiting } \\
\text { hydrogeological } \\
\text { settings (USEPA, } \\
\text { 2006). Rapid } \\
\text { oxidant reaction } \\
\text { rates (esp. } \mathrm{H}_{2} \mathrm{O}_{2} \text {, } \\
\mathrm{Fe}^{2+} \text {, and } \mathrm{O}_{3} \text { ) where } \\
\text { oxidant demand } \\
\text { may be high in some } \\
\text { soils/aquifers }\end{array}$ & $\begin{array}{l}\text { Contamination } \\
\text { transference: } \\
\text { environmental issues } \\
\text { concerning soil are } \\
\text { merely leachate } \\
\text { transferred to landfill } \\
\text { site }\end{array}$ & $\begin{array}{l}\text { High energy costs and } \\
\text { potential difficulties } \\
\text { due to surface } \\
\text { infrastructure } \\
\text { requirements. Not } \\
\text { suitable for inorganic } \\
\text { contaminants }\end{array}$ \\
\hline $\begin{array}{l}\text { How EK can } \\
\text { help }\end{array}$ & $\begin{array}{l}\text { Electromigration } \\
\text { and/or electro- } \\
\text { osmosis can deliver } \\
\text { nutrients, } \\
\text { microorganisms to } \\
\text { target zone }\end{array}$ & $\begin{array}{l}\text { Electromigration } \\
\text { can bring pollutants } \\
\text { to roots for easier } \\
\text { phytostabilisation, } \\
\text { rhizofiltration or } \\
\text { rhizodegradation(A } \\
\text { boughalma et al., } \\
\text { 2008; Cameselle et } \\
\text { al., 2013a) }\end{array}$ & $\begin{array}{l}\text { Electrophoresis (if } \\
\text { sandy soil) and/or } \\
\text { electro-osmosis (if } \\
\text { clayey soil) can } \\
\text { enhance nanoparticle } \\
\text { delivery to } \\
\text { contaminated } \\
\text { regions; faster } \\
\text { nanoparticle } \\
\text { transport than } \\
\text { natural hydraulic } \\
\text { conductivity }\end{array}$ & $\begin{array}{l}\text { Oxidant delivery to } \\
\text { contaminated } \\
\text { regions; faster } \\
\text { oxidant delivery } \\
\text { than natural } \\
\text { hydraulic } \\
\text { conductivity }\end{array}$ & $\begin{array}{l}\text { Electro-osmosis can be } \\
\text { used to dewater } \\
\text { soil/sediment/waste and } \\
\text { reduce total residue } \\
\text { weight/volume for } \\
\text { landfilling; metals or } \\
\text { organic contaminants } \\
\text { can be extracted ex-situ } \\
\text { through the } \\
\text { electrodialytic method } \\
\text { and avoid landfill all- } \\
\text { together (Pernille E. } \\
\text { Jensen et al., 2007; Ana T } \\
\text { Lima et al., 2012; }\end{array}$ & $\begin{array}{l}\text { Not amenable to } \\
\text { improvement through } \\
\text { EK approaches }\end{array}$ \\
\hline
\end{tabular}




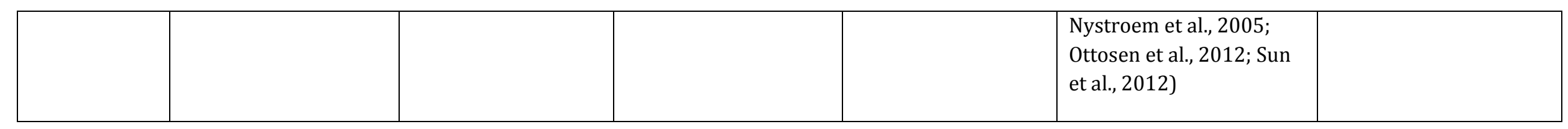

